\title{
UNITED STATES' BANKRUPTCY JURISDICTION OVER FOREIGN ENTITIES: EXORBITANT OR CONGRUENT?
}

\author{
Adrian Walters
}

This is an Author's Original Manuscript (preprint) of an article accepted for publication by Taylor \& Francis in the Journal of Corporate Studies. 


\title{
UNITED STATES' BANKRUPTCY JURISDICTION OVER FOREIGN ENTITIES: EXORBITANT OR CONGRUENT?
}

\begin{abstract}
Adrian Walters*
Alarmed at the ease with which global bankruptcy jurisdiction can be engineered in the United States through a combination of the Bankruptcy Code's low bar to entry and the worldwide effects of a bankruptcy case, critics argue that the US promotes abusive bankruptcy forum shopping and harmful imposition of US norms on overseas stakeholders. This article advances a revised account of US bankruptcy jurisdiction over non-US debtors from a distinctively Anglo-American standpoint. The article's central thesis is that critics overemphasize formal jurisdictional rules and pay insufficient attention to how US courts actually exercise jurisdiction in practice. It compares the formal law 'on the books' in the US and UK for determining whether or not a domestic insolvency or restructuring proceeding relating to a foreign debtor can be maintained in each jurisdiction and provides a functional account of how US bankruptcy jurisdiction over foreign entities is exercised in practice using the concept of jurisdictional congruence as a benchmark. While American and British approaches to abusive forum shopping are on different legal cultural paths, the article also identifies reasons for thinking that they are trending towards rough functional equivalence influenced, at least in part, by the US's commitment to the UNCITRAL Model Law. In sum, the article lays foundations for further critical reflection on the roles that judges, practitioners and the 'centre of main interests' principle play in configuring the market for international bankruptcy case filings and in facilitating and regulating forum shopping in that market. Through the lens of legal development, it also presents some practical and policy challenges for universalism, international insolvency law's dominant theory.
\end{abstract}

\section{INTRODUCTION}

The record of the United States in recognizing foreign insolvency proceedings and giving effect to foreign insolvency law within its territorial jurisdiction in transnational insolvency cases is second to none. Bankruptcy courts routinely extend comity to foreign restructuring plans and, in so doing, permit foreign insolvency law to discharge or modify obligations under US law governed transactions. ${ }^{1}$ This practice, established before the

* IIT Chicago-Kent College of Law (US); Centre for Business and Insolvency Law, Nottingham Law School, Nottingham Trent University (UK), awalters@kentlaw.iit.edu. I thank participants in the INSOL International Academics' Colloquium held in London in July 2016 for comments on an early version of this article. I also thank Tim Barnes, Allan Gropper, Ian Fletcher, Daniel Glosband, Steve Harris, Melissa Jacoby, Bruce Markell, Rick Mason, John Pottow, Sarah Paterson, Charles Tabb, Jay Westbrook, Tally Mindy Wiener and Ian Williams for helpful discussions and comments; Cody Lipke (ChicagoKent Class of 2018) for research assistance. The article was supported by a generous summer grant from the Chicago-Kent College of Law. The usual disclaimers apply. A terminological note is in order. 'Bankruptcy law' in the US encompasses business entities 
US enacted the UNCITRAL Model Law on Cross-Border Insolvency ${ }^{2}$ in 2005 as chapter 15 of the Bankruptcy Code, has accelerated since. ${ }^{3}$ US courts resist attempts by US-based holdout creditors to resort to US lawsuits ${ }^{4}$ or US involuntary bankruptcy proceedings ${ }^{5}$ as a mechanism to improve their negotiating position in foreign insolvency proceedings already commenced in the jurisdiction where the debtor has its centre of main interests ('COMI'). And they are much more willing than their UK counterparts to permit foreign insolvency law to override party autonomy expressed through choice of law and venue clauses in contracts and financing instruments. ${ }^{6}$

But US courts also allow forum shopping non-US entities to file full chapter 11 bankruptcy proceedings in the US. ${ }^{7}$ And, in this respect, as far as its critics are concerned, the US comes unstuck. Critics are alarmed at the ease with which global bankruptcy jurisdiction can be engineered, through a combination of the Bankruptcy Code's low bar to entry, ${ }^{8}$ and the worldwide reach of the automatic stay and the bankruptcy estate. Cases like Avianca $^{9}$ (a successful US chapter 11 case filed by Colombia's national airline) and $\operatorname{Yukos}^{10}$ (a US chapter 11 case filed by a Russian oil giant that restrained certain banks from participating in an expropriatory tax auction) are

and natural persons whereas in the UK and the Commonwealth its scope is limited to natural persons and the law governing the insolvency of business entities is referred to as 'corporate insolvency law'. This article uses 'bankruptcy' in the wider US sense of the term. Any references to 'bankruptcy' and 'insolvency' are interchangeable. All uniform resource locators cited in footnotes were live on 16 February 2017.

${ }^{1}$ See A Walters, 'Giving Effect to Foreign Restructuring Plans in Anglo-US Private International Law' (2015) 3 NIBLeJ 37.

${ }^{2}$ UNCITRAL Model Law on Cross-Border Insolvency (1997) with Guide to Enactment (2013), UN Sales No E 14 V2 (2014).

${ }^{3}$ See eg Canada Southern Ry Co v Gebhard (1883) 109 US 527, In re Board of Directors of Multicanal S.A. (2004) 314 BR 486. UK schemes of arrangement relating to non-UK entities have been a particular beneficiary of US largesse: see Walters (n 1).

${ }^{4}$ See eg JP Morgan Chase Bank v Altos Hornos de Mexico, S.A. de C.V. 412 F.3d 418 $\left(2^{\text {nd }}\right.$ Cir 2005) and other Second Circuit authorities discussed in In re Northshore Mainland Services, Inc (2015) 537 BR 192, 207. See also KA Mayr, 'Enforcing Prepackaged Restructurings of Foreign Debtors Under the US Bankruptcy Code' (2006) 14 Am Bankr Inst L Rev 469, 504 (text to footnote 129 citing to extensive authority illustrating invocation by US courts of comity to dismiss lawsuits in deference to foreign insolvency proceedings).

${ }^{5}$ Multicanal (n 3). See also In re Compañia de Alimentos Fargo, SA (2007) 376 BR 427.

${ }^{6}$ Compare Altos Hornos (n 4) 428-429 and Fibria Celulose S/A v Pan Ocean Co Ltd [2014] EWHC 2124 (Ch), [2014] Bus LR 1041.

${ }^{7}$ See O Couwenberg \& SJ Lubben, 'Corporate Bankruptcy Tourists' (2015) 70 Bus L 719.

8 'A dollar, a dime, or a peppercorn' of property in the US suffices: see In re Theresa Mctague (1996) 198 BR 428, 431.

${ }^{9}$ In re Aerovias Nacionales de Colombia S.A. Avianca (2003) 303 BR 1.

${ }^{10}$ In re Yukos Oil Co (2005) 321 BR 396. 
viewed as exemplars of US exorbitance. ${ }^{11}$ The consequence of such unseemliness, critics claim, is a 'parade of horribles': abusive forum shopping designed to benefit debtors at the expense of creditors; imposition of US law on remote stakeholders; US overreaching at the expense of other countries' policy choices; costly inconvenience for foreign creditors forced to contest US jurisdiction; risk of contempt sanctions for foreign creditors who have a presence in the US; and increased risk of jurisdictional conflict. For the critics, undesirable aspects of American exceptionalism are at large. By asserting global jurisdiction in transnational insolvencies on a flimsy basis, the US encourages harmful forum shopping and engages in hubristic export of US norms. The normative implication is that the US should raise its barrier to entry making it harder for forum shopping foreign debtors to file under chapter 11. As Professor McCormack, a critic of Avianca and Yukos, puts it: '[i]f the jurisdictional threshold was higher, this would reduce the risk of inappropriate proceedings being filed. ${ }^{12}$

This article - which advances a revised account of US bankruptcy jurisdiction over non-US debtors from a distinctively Anglo-American standpoint ${ }^{13}-$ is more sanguine. Its central thesis is that critics overemphasize formal jurisdictional rules and pay insufficient attention to how US courts actually exercise jurisdiction in practice. I proceed as follows. Part II sketches the emergent system for judicial coordination of transnational insolvencies in the US and the EU. Also discussed are the influence of domestic courts on bankruptcy forum shopping and the normative implications of universalism - international insolvency law's dominant theory - for the exercise of domestic bankruptcy jurisdiction in transnational cases. Part III focuses on the influence of local jurisdictional rules on forum shopping. In particular, I compare the formal law 'on the books' in the US and UK for determining whether or not a domestic insolvency or restructuring proceeding relating to a foreign debtor can be maintained in each jurisdiction. Part IV discusses how US bankruptcy jurisdiction over foreign entities is exercised in practice using the concept of jurisdictional congruence as a benchmark. Part IV draws on common aspects of restructuring practice, and on what I call 'legal development' cases, ${ }^{14}$ to illustrate US courts' creativity and restraint. Under the 'legal development' rubric I revisit Avianca and consider In re Northshore Mainland Services,

${ }^{11}$ G McCormack, 'Bankruptcy Forum Shopping: The UK and US as Venues of Choice for Foreign Companies' (2014) 63 ICLQ 815, 816, 822-824, 836-839, 841-842; G Affaki, 'A European View on the US Courts' Approach to Cross-Border Insolvency - Lessons from Yukos' in G Affaki (ed), Cross-Border Insolvency and Conflict of Jurisdictions: A US-EU Experience (Bruylant, 2007).

${ }^{12}$ McCormack (n 11) 838.

${ }^{13}$ The author is currently based in the US but is originally from, and spent the majority of his career to date in, the UK. He is a participant in, and an observer of, both legal systems. See further W Twining, Globalisation \& Legal Theory (Butterworths 2000) 129-133.

${ }^{14}$ Cases where the underdevelopment of insolvency law and/or its supporting institutional infrastructure in the debtor's home country influences the debtor, often in conjunction with its senior creditors and other stakeholders, to shop for bankruptcy resolution in a mature and relatively more predictable system. 
Inc, ${ }^{15}$ a more recent case from the District of Delaware. I argue that the way US courts exercise bankruptcy jurisdiction is actually more restrained than critics would have us believe. Part V develops a tentative argument for US-UK functional convergence in the regulation of forum shopping. While American and British approaches to abusive forum shopping are on different legal cultural paths, I identify reasons for thinking that they are trending towards rough functional equivalence and that US practice has plausibly evolved a decade on from magnets for criticism such as Avianca, Yukos and Cenargo. ${ }^{16}$ Moreover, the direction of travel is, I suggest, influenced at least in part, by the US's commitment to the UNCITRAL Model Law, an instrument which confers global legitimacy on 'main' insolvency proceedings commenced in the country of the debtor's COMI. Part VI outlines the chapter 11 case of Arcapita, a Bahraini investment bank, to illustrate how power and development imbalances will hold back spontaneous emergence of a symmetrical, universalistic, approach to international bankruptcy jurisdiction in the absence of a global convention. Part VII concludes. In sum, the article lays foundations for further critical reflection on the roles that judges, practitioners and the COMI principle play in configuring the market for international bankruptcy case filings and in facilitating and regulating forum shopping in that market. Through the lens of legal development, it also presents some practical and policy challenges for universalism.

\section{THE INTERNATIONAL SYSTEM FOR COORDINATING TRANSNATIONAL INSOLVENCIES}

\section{A. Legal framework}

International insolvencies give rise to obvious coordination difficulties. These difficulties are currently addressed in broadly two ways: directly, by private international law instruments, notably the EU Insolvency Regulation ${ }^{17}$ and the UNCITRAL Model Law, and, indirectly, by harmonization initiatives of varying intensity designed to foster convergence among national insolvency laws ${ }^{18}$ and cooperation in transnational insolvency cases. ${ }^{19}$ The lack of any global insolvency treaty reflects a longstanding

${ }^{15}$ (2015) 537 BR 192.

${ }^{16}$ In re Cenargo International Plc (2003) 294 BR 571. See further McCormack (n 11) 836.

${ }^{17}$ Regulation (EU) 2015/848 on insolvency proceedings (recast) [2015] OJ L141/19 ('EU Insolvency Regulation') which applies to insolvency proceedings opened after 26 June 2017. Insolvency proceedings opened before that date will continue to be governed by Council Regulation (EC) No 1346/2000 [2000] OJ L160/1.

${ }^{18}$ See eg UNCITRAL, Legislative Guide on Insolvency Law (Parts One and Two 2004, Part Three 2010, Part Four 2014)

$<$ http://www.uncitral.org/uncitral/en/uncitral texts/insolvency/2004Guide.html>; Commission Recommendation 2014 of 12 March 2014 on a new approach to business failure and insolvency [2014] OJ L74/65.

${ }^{19}$ The American Law Institute and the International Insolvency Institute, Transnational Insolvency: Global Principles for Cooperation in International Insolvency Cases (ALI 2012). 
assumption that national insolvency laws are so infused with idiosyncratic domestic policy commitments that international consensus on 'prickly' issues, ${ }^{20}$ such as distributional priorities and avoiding powers, is hard to accomplish. ${ }^{21}$ However, in the realm of judicial cooperation and harmonized private international law, progress in transnational coordination has been made. Practitioners and courts have fashioned solutions in cases of breathtaking complexity. The multi-jurisdictional resolution of causes célébres such as the Maxwell, Lehman and Nortel insolvencies would have been inconceivable fifty years ago. ${ }^{22}$ And so despite territorial, geopolitical and theoretical constraints on the feasibility of international cooperation, ${ }^{23}$ meaningful cooperation has happened in practice.

Regional and international lawmaking has contributed to this steady progress. The EU Insolvency Regulation - now in its second iteration - takes a typical 'double convention' style of approach, ${ }^{24}$ harmonizing rules on allocation of jurisdiction to open insolvency proceedings, applicable law and recognition of insolvency proceedings and insolvency-related judgments throughout the EU. The UNCITRAL Model Law - has been enacted by forty-one countries across the globe. ${ }^{25}$ Compared to the EU Insolvency Regulation, the Model Law is a weaker, less comprehensive, 'private international law light' ${ }^{26}$ instrument that, by design, steers clear of a prescriptive approach to choice of law issues, pursuing instead a pragmatic, incremental strategy aimed at building international consensus around a series of norms that are primarily procedural in character. ${ }^{27}$

\footnotetext{
${ }^{20} \mathrm{~J}$ Pottow, 'Procedural Incrementalism: A Model for International Bankruptcy' (2005) 45 Va J Int'1 L 935, 941. See also S Block-Lieb \& T Halliday, 'Incrementalisms in Global Lawmaking' (2007) 32 Brook J Int'l Law 851, 855-856.

${ }^{21}$ For historical insight, see S Block-Lieb, 'Turnaround: Reflections on the Present Day Influence of Negotiations on International Bankruptcy at the Fifth Session of the Hague Conference on Private International Law in 1925' (2014) 9 Brook J Corp Fin \& Com L 1. ${ }^{22}$ See eg J Westbrook, 'The Lessons of Maxwell Communication' (1996) 64 Fordham LR 2531; J Altman, 'A Test Case in International Bankruptcy Protocols: The Lehman Brothers Insolvency' (2011) 12 San Diego Int'1 LJ 463; LL Peacock, 'A Tale of Two Courts: The Novel Cross-Border Bankruptcy Trial' (2015) 23 Am Bankr Inst L Rev 543. ${ }^{23}$ F Tung, 'Is International Bankruptcy Possible?' (2001) 23 Mich J Int'l L 31.

${ }^{24}$ S Block-Lieb \& T Halliday, 'Less is More in International Private Law' (2015) 3 NIBLeJ 4, [24]. The EU Regulation's original text was derived from an earlier, lapsed Bankruptcy Convention that was itself a product of around thirty years' of 'on-off' negotiations: see M Balz, 'The European Convention on Insolvency Proceedings' (1996) 70 Am Bankr LJ 485.

${ }^{25}$ Including all the NAFTA countries (Canada, Mexico, the US), the leading countries of the Asia-Pacific Rim (Australia, Japan, New Zealand), the OHADA countries and the UK. For the current list of adopting countries see $<$ http://www.uncitral.org/uncitral/en/uncitral_texts/insolvency/1997Model_status.html $>$. ${ }^{26}$ Block-Lieb \& Halliday (n 24), [26].

${ }^{27}$ See further Pottow (n 20); Block-Lieb \& Halliday (n 20); J Clift, 'Choice of Law and the UNCITRAL Harmonization Process' (2014) 9 Brook J Corp Fin \& Com L 20. For comparison of the Model Law and the EU Insolvency Regulation see also I Mevorach,
} 
Both instruments contemplate that an international insolvency case will comprise a single proceeding taking place in the state where the debtor's COMI is located or a series of concurrent proceedings taking place in more than one state with which the debtor is substantially connected. ${ }^{28}$ Both instruments accord primacy to a 'main' insolvency proceeding conducted in the state of the debtor's COMI and reflect, with varying degrees of potency, the universalist ideal of 'a unitary bankruptcy proceeding in a bankrupt's 'home' country, which applies universally to all the bankrupt's assets and which receives worldwide recognition. ${ }^{29}$ In this 'single main proceeding' mode, foreign representatives of insolvent estates expect to have their authority to act under COMI law recognized with minimal procedural formality in other countries where there are assets and creditors ${ }^{30}$ and to enjoy access to, and cooperation from, the courts of those other countries in administering the estate's affairs, whether in pursuit of an orderly windingup or a coordinated rescue strategy. ${ }^{31}$

The alternative 'concurrent proceeding' mode acknowledges the reality that in a world of divergent interests in which territorially based jurisdiction persists, and assets and creditors are situated in many locations, two or more countries may conceivably assert jurisdiction in relation to the same debtor entity. While the EU Insolvency Regulation and the Model Law handle this mode differently, both instruments seek to avoid jurisdictional conflicts by espousing open-ended norms of international cooperation, designed to encourage courts and estate representatives in concurrent

'On the Road to Universalism: A Comparative and Empirical Study of the UNCITRAL Model Law on Cross-Border Insolvency’ (2011) 12(4) EBOR 517, 522-528.

${ }^{28}$ See further Transnational Insolvency: Global Principles (n 19) 34.

${ }^{29} \mathrm{G}$ McCormack, 'Universalism in Insolvency Proceedings and the Common Law' (2012) 32 OJLS 325. See further EU Insolvency Regulation, recitals (23), (24), (48), arts $3,7,19-21,33$ (delineating scope and effects of 'main' and 'secondary' proceedings); UNCITRAL Model Law, arts 2, 15-17, 20-22 (providing for recognition of 'foreign main' and 'foreign non-main' insolvency proceedings and delineating the relief available in each type of proceeding). Space does not permit a full exposition of the COMI concept. For instructive case law see Case C-341/04 In re Eurofood IFSC Ltd [2006] Ch 508; Case C-396/09 Interedil Srl (in liquidation) v Fallimento Interedil Srl [2012] Bus LR 1582. Secondary or non-main proceedings also qualify for international recognition where the debtor has an establishment in the country in which the proceedings are opened. The concept of establishment across the two instruments is virtually identical. It denotes some kind of meaningful economic presence: EU Insolvency Regulation, art 2(10); UNCITRAL Model Law, art 2(f).

${ }^{30}$ EU Insolvency Regulation, recital 65, arts 19-21 (providing for recognition and effects of insolvency proceedings and pan-EU powers of insolvency practitioner); UNCITRAL Model Law, arts 15-17 (setting out the rules governing an application for recognition by a foreign representative).

${ }^{31}$ EU Insolvency Regulation, art 21 (conferring powers on 'main' proceeding insolvency practitioner to act in other member states), art 32 (providing for recognition and enforcement of insolvency-related judgments); UNCITRAL Model Law, arts 7, 9-12, 1923 (providing foreign representatives with access rights and various forms of relief pending and following recognition of a foreign insolvency proceeding). 
proceedings to communicate and cooperate with the aim of facilitating coordinated solutions and procedural efficiencies, but without undermining the jurisdictional integrity of the courts involved. ${ }^{32}$ These norms are grounded in practitioner innovations, such as court-approved protocols, and developments in inter-court communication. ${ }^{33}$

Thus, even without an international insolvency treaty, foreign representatives may typically now perform many basic operations abroad, such as protecting overseas assets from enforcement through a local stay, releasing local attachments, and coordinating management of claims and distributions with local courts or bankruptcy trustees, with relative ease. Although the threshold jurisdictional criteria (COMI or establishment) disfavour 'letterbox' entities incorporated in offshore tax havens, ${ }^{34}$ the empirical evidence to date confirms that the Model Law has been effective in facilitating streamlined recognition of foreign insolvency proceedings. 35

\section{B. Domestic courts, global governance and forum shopping}

In a system where instruments of private international law provide the framework for coordination of transnational commercial activity, domestic courts play a frontline role in global governance. ${ }^{36}$ In the transnational insolvency context, domestic courts allocate governance authority by deferring, or not deferring, to the primacy of foreign main insolvency proceedings as regards assets and claimants within their territorial jurisdiction. Binary decisions by courts to assume bankruptcy jurisdiction over a person or entity rather than defer to a foreign court on forum non conveniens grounds, or to grant rather than deny recognition to a foreign insolvency proceeding, or to apply local priority rather than foreign priority rules to the distribution of local assets, or to domesticate rather than refuse to domesticate a foreign bankruptcy court judgment, all affect how governance authority is allocated and exercised among states. ${ }^{37}$ How these decisions play out in domestic courts around the world over time in turn affects the strategic decision-

${ }^{32}$ EU Insolvency Regulation, recitals (48)-(50), arts 41-43; UNICTRAL Model Law, arts 25-30 (providing for cooperation and communication between courts and across various other dimensions). See further Transnational Insolvency: Global Principles (n 19) Sections I \& II. Some progress has also been made as regards coordination of insolvency proceedings involving corporate groups: EU Insolvency Regulation, ch V; UNCITRAL, Legislative Guide on Insolvency Law (Part Three 2010).

${ }^{33}$ Transnational Insolvency: Global Principles (n 19) Sections I \& II. The legislative preference is for the proceeding in the COMI country to be predominant and any concurrent proceeding to be circumscribed accordingly.

${ }^{34}$ A Dawson, 'Offshore Bankruptcies' (2009) 88 Neb L Rev 317.

${ }^{35}$ Mevorach (n 27); J Leong, 'Is Chapter 15 Universalist or Territorialist? Empirical Evidence from United States Bankruptcy Cases' (2011) 29 Wis Int'l LJ 110; JL Westbrook, 'An Empirical Study of the Implementation in the United States of the Model Law on Cross-Border Insolvency (2013) 87 Am Bankr LJ 247.

${ }^{36}$ See generally R Michaels, 'Global Problems in Domestic Courts' in Muller et al (eds), The Law of the Future and the Future of the Law (TOAEP 2011) 165, 173-174.

${ }^{37}$ See generally C Whytock, 'Domestic Courts and Global Governance' (2009) 84 Tul L Rev 67. 
making of transnational actors, especially debtors, senior creditors, and their professional advisers.

If we conceive of forum shopping for bankruptcy resolution in crude market terms, the legal environment consisting of rules, standards and institutions shapes the 'supply' side while capital structures, power dynamics and dimensions of control among key stakeholders shape the 'demand' side. Consistent application of legal standards by courts creates predictability on the 'supply' side. 'Demand' side decisions depend on interactions among those stakeholders who have functional control of the debtor entity's decision making - often, senior creditors ${ }^{38}$ - and the professional advisers who act as case placers. Thus, there is a 'feedback loop' between domestic court decisions that allocate governance authority in transnational cases and subsequent decisions by debtors and case placers to select a particular venue for insolvency proceedings. ${ }^{39}$ Of course, forum shopping decisions are also influenced by substantive considerations. Shoppers will prefer the bankruptcy system with the legal and procedural dispensation most likely to deliver the substantive outcomes they desire in real time in predictable and timely fashion. Nevertheless, if the domestic court in the preferred venue is unlikely to assert bankruptcy jurisdiction in a transnational case or will struggle to have its jurisdiction recognized in other countries, any substantive advantages of that venue's bankruptcy system may be illusory.

The growth in the market for UK Companies Act schemes of arrangement in relation to non-UK companies illustrates how domestic court decisions in more than one country combine to configure forum shopping choices. UK courts consistently approve schemes of arrangement proposed by foreign companies, taking jurisdiction on the basis of a 'sufficient connection' with the UK. ${ }^{40}$ Schemes have attracted a favourable market perception among foreign entities and case placers because they are not strictly insolvency proceedings and are accessible without proof of insolvency. The apparent

${ }^{38}$ There is now an extensive literature on the role of lenders in the governance of bankruptcies and its impact on outcomes. See eg JL Westbrook, 'The Control of Wealth in Bankruptcy' (2004) 82 Tex LR 795; J Armour et al, 'The Costs and Benefits of Secured Creditor Control in Bankruptcy: Evidence from the UK' (2012) 8 Review of Law \& Econ 101. Space does not permit elaboration of the point but there is a tendency in bankruptcy forum shopping literature to assume that debtors are relatively unconstrained in the choices they make. The assumption prompts the worry that debtors will choose pro-debtor bankruptcy law and impose it to the disadvantage of uncoordinated, widely dispersed creditors and equity interests. The idea that distressed transnational corporate debtors can freely shop is a myth that pays scant attention to capital structures in the real world and the power dynamics that they generate. In a world where capital structures are highly leveraged, lenders call the shots, not debtors and managers. See, relatedly, A Schwarz, 'Bankruptcy Related Contracting and Bankruptcy Functions' available at $<$ http://papers.ssrn.com/sol3/papers.cfm?abstract id=2806027>. ${ }^{39}$ See Whytock (n 37) 96-114 characterizing domestic court decisions that affect the behaviour of transnational actors as the 'transnational shadow of the law.' The role of feedback loops, drawn from complexity theory, is developed below in Part V.

${ }^{40}$ See Walters (n 1). On 'sufficient connection' as a jurisdictional hook see further Part III below. 
willingness of courts in other European countries to give effect to UK schemes based on connections such as English choice of law and jurisdiction clauses in the debtor's financing instruments has helped consolidate the UK's position as the EU's premier venue for financial restructuring. ${ }^{41}$ UK schemes are also used to restructure New York law governed bonds in the high yield market. In these restructurings, it is established practice for non-UK debtors to deploy a range of techniques, including migrating their COMIs by moving headquarters to the UK before proposing a scheme. As well as satisfying the UK's threshold jurisdictional requirement of a 'sufficient connection', a COMI migration makes the scheme exportable to the US as a foreign main proceeding through the portal of chapter 15 of the Bankruptcy Code. US courts routinely recognize and give binding effect to such schemes in the US and, in so doing, underwrite the efficacy of UK schemes. ${ }^{42}$ The pattern of US acquiescence enhances the predictability and appeal of this species of forum shopping to debtors and case placers.

\section{Universalism and domestic bankruptcy jurisdiction: the 'ideal' and the 'real'}

Universalists regard instruments like the UNCITRAL Model Law as a staging post on the journey towards ultimate realization of their 'ideal' - a single primary bankruptcy proceeding in the debtor's home country, with courts elsewhere assisting the 'home' (COMI) court to achieve unitary administration of assets under 'home' (COMI) bankruptcy law. ${ }^{43}$ They seek to globalize the welfare benefits of domestic bankruptcy law systems, namely: (i) aggregate value maximization achieved through collective proceedings that prevent a run on the debtor's assets and (ii) equivalent treatment of

${ }^{41}$ J Payne, 'Cross-Border Schemes of Arrangement and Forum Shopping' (2013) 13(4) EBOR 563. The scheme of arrangement is outside the scope of the EU Insolvency Regulation with the consequence that the Regulation's venue and recognition rules, predicated on the debtor having its COMI or an establishment in the country where insolvency proceedings are opened, do not apply. The willingness of EU member states to accept the effect of English schemes is influenced by other aspects of the EU acquis, notably Regulation (EC) No 593/2008 of the European Parliament and of the Council of 17 June 2008 on the law applicable to contractual obligations (Rome I) [2008] OJ L177/6 and Regulation (EU) 1215/2012 of the European Parliament and of the Council of 12 December 2012 on jurisdiction and the recognition and enforcement of judgments in civil and commercial matters (the Recast Brussels Regulation) [2012] OJ L351/1. The UK's withdrawal from the EU following the electorate's vote for 'Brexit' in the referendum on 23 June 2016 will radically affect the legal environment unless the UK and EU agree to alternative arrangements for mutual recognition in this area of private international law whether on a transitional or a permanent basis.

${ }^{42}$ Walters (n 1). For recent examples see In re Magyar Telecom BV [2013] EWHC 3800 (Ch), [2014] BCC 448; In re Zlomrex International Finance SA [2013] EWHC 3866 (Ch); In re DTEK Finance BV [2015] EWHC 1164 (Ch); In re Codere Finance (UK) Ltd [2015] EWHC $3778(\mathrm{Ch})$. It is important to add the qualifier that the grant of recognition and relief to these schemes in the US has invariably been unopposed.

${ }^{43}$ JL Westbrook, 'National Regulation of Multinational Default' in M Monti et al (eds), Economic Law and Justice in Times of Globalisation (Nomos 2007) 777, 778-779. 
similarly situated creditors, under a single law and a single, collective claims resolution process. ${ }^{44}$ The goal is to move as far, and as quickly as possible, from territorialism - an uncoordinated state-centric 'system' in which each jurisdiction 'grabs' and administers locally situated assets under local law in piecemeal fashion for the benefit of locally situated creditors. Universalists contend that territorialism reproduces in the international context all of the welfare problems that bankruptcy laws are designed to address domestically: costly, duplicative claims enforcement; destruction of going concern value; asymmetric distributional outcomes favouring some creditors over others; and high costs of lending ex ante because of the lack of a coordinated, predictable exit for lenders in the event of default. ${ }^{45}$ Territorialists worry about the imposition of the debtor's home bankruptcy law on remote stakeholders and the implications of universalism for state sovereignty, especially the implications for local priority rules infused with local policy choices. ${ }^{46}$ They are sovereigntists who prefer cooperation among sovereigns to the global hegemony of a single law. While the debate has been influential, my purpose is not to engage with it here. But I do need to consider briefly the normative implications of universalism for the allocation of governance authority in transnational cases by domestic courts.

Universalism and territorialism are bookends - opposite extremes on a spectrum neither of which adequately captures the way the international bankruptcy system functions. Universalists concede that 'the ideal remains some distance away' ${ }^{47}$ and characterize the present state of affairs as 'modified universalism', a transitional 'system' which tries to approximate, through international cooperation, the outcomes of a pure universalist system, while accommodating protections for local creditors and sovereign

\footnotetext{
${ }^{44}$ The article assumes that readers are generally familiar with the debate between universalists and territorialists regarding the most suitable model for resolving transnational insolvencies. The universalist position is staked out in JL Westbrook, 'Theory and Pragmatism in Global Insolvencies: Choice of Law and Choice of Forum' (1991) 65 Am Bankr LJ 457; 'A Global Solution to Multinational Default (2000) 98 Mich LR 2276. As much of the literature is American, it is no great surprise that universalism in its pure, platonic form looks much like a global projection of US federal bankruptcy law, which is a single, 'meta' law that stays and resolves claims arising throughout the US under the laws of multiple sovereign states.

${ }^{45}$ Westbrook (n 43).

${ }^{46}$ LM Lopucki, 'The Case for Cooperative Territoriality in International Bankruptcy' (2000) 98 Mich LR 2216; JJ Chung, 'The New Chapter 15 of the Bankruptcy Code: A Step Towards Erosion of National Sovereignty' (2006) 27 NW J Int'l L \& Bus 89. See also SM Franken, 'Cross-Border Insolvency Law: A Comparative Institutional Analysis' (2014) 34 OJLS 97, 98 ('The fundamental difference between territorialism and universalism is that in the case of territorialism, states are guaranteed of the application of their own insolvency law to assets located in their jurisdiction, whereas in the case of universalism, states need to accept that foreign law may apply to assets located in their jurisdiction').

${ }^{47}$ Westbrook (n 43) 779.
} 
state interests. ${ }^{48}$ Despite the concession, for universalists, what matters is the journey towards their desired end goal - a single, global insolvency proceeding conducted in the jurisdiction of the debtor's COMI in accordance with COMI law. So the questions that interest them are questions about how we can best progress from the 'transitional' to the 'ideal', be that through low level procedural harmonization designed to prepare the ground for more intensive cooperation, ${ }^{49}$ international choice of law rules, ${ }^{50}$ a global interpretive sensibility in judicial handling of Model Law-based domestic enactments, ${ }^{51}$ or other mechanisms.

In the universalists' ideal world, the debtor's COMI would serve as a uniform, global jurisdictional and choice of law rule and other countries where there are assets or claims needing to be administered would fall into line and adopt an ancillary posture without opening local insolvency proceedings. Universalism would therefore mimic a global double convention with the debtor's COMI determining jurisdiction, choice of law and recognition of the 'home' insolvency proceeding elsewhere. Under conditions of pure universalism, local rules of bankruptcy jurisdiction applicable in domestic cases would be overridden in transnational cases and courts would allocate governance authority accordingly. There is a lively debate about whether or not universalism would lead to rampant bankruptcy forum shopping with views differing on the predictability and manipulability of the COMI test. ${ }^{52}$ Experience in Europe, including the experience relating to UK schemes of arrangements described earlier, suggests that debtors can easily manipulate COMI for bankruptcy forum shopping purposes. ${ }^{53}$ But the degree to which COMI can be manipulated is not my present concern. COMI is the jurisdictional grundnorm underlying the entire universalist system and, for universalists, the debtor's COMI should determine how governance authority is allocated in transnational cases as a normative matter.

In the real world, under conditions of modified universalism, domestic rules of bankruptcy jurisdiction remain salient and affect forum shopping. The EU Insolvency

${ }^{48}$ See eg E Adams \& J Fincke, 'Coordinating Cross-Border Bankruptcy: How Territorialism Saves Universalism' (2009) 15 Colum J Eur L 43; J Pottow, 'Beyond Carve-Outs and Toward Reliance: A Normative Framework for Cross-Border Insolvency Choice of Law' (2014) 9 Brook J Corp Fin \& Com L 202. The Model Law is generally characterized as an instrument of modified universalism. See eg JL Westbrook, 'Chapter 15 at Last' (2005) 79 Am Bankr LJ 713, 719; Mevorach (n 27) 520.

${ }^{49}$ Pottow (n 20).

${ }^{50}$ Pottow (n 48).

${ }^{51}$ JL Westbrook, 'Interpretation Internationale' (2015) 87 Temp L Rev 739.

52 LM Lopucki, 'Global and Out of Control?' (2005) 79 Am Bankr LJ 79; S Bufford, 'Global Venue Controls Are Coming: A Reply to Professor Lopucki' (2005) 79 Am Bankr LJ 105; LM Lopucki, 'Universalism Unravels' (2005) 79 Am Bankr LJ 143; J Pottow, 'The Myth (and Realities) of Forum Shopping in Transnational Insolvency' (2007) 32 Brook J Int'1 Law 785.

${ }^{53}$ In the European context see eg Case C-396/09 Interedil Srl (in liquidation) $v$ Fallimento Interedil Srl [2012] Bus LR 1582. Art 3(1) of the EU Insolvency Regulation now places a modest limit on the ability of debtors to move their registered offices to another Member State within three months of a bankruptcy filing. 
Regulation has moved closer to the universalist ideal than the Model Law by harmonizing rules of bankruptcy jurisdiction, applicable law and recognition. However, in cases outside the EU, or cases having an extra-European dimension, jurisdictional rules are not harmonized. Thus, debtors have opportunities to forum shop in powerful countries like the US that have low barriers to entry, falling short of the COMI threshold, coupled with long-arm jurisdiction. In the real world, the questions for debtors, stakeholders and case placers are: (i) can we achieve our goals through an insolvency proceeding in this particular jurisdiction compared to other jurisdictions; and (ii) to the extent we need to export the effects of the proceeding to other countries, are we confident that other countries will cooperate? Thus, we can expect forum shopping to persist insofar as there are legal or procedural advantages to be gained from it even in the face of harmonization initiatives of various kinds. $^{54}$

Universalists acknowledge these realities but prefer domestic courts to exercise bankruptcy jurisdiction commensurate with the Model Law's rules for recognition of foreign main and foreign non-main proceedings. If courts acted according to this universalist preference, it would produce a rough symmetry. Courts would only ever assert bankruptcy jurisdiction over foreign entities on the same criteria, and to the same extent, that they would recognize foreign insolvency proceedings relating to those entities: worldwide jurisdiction based on COMI or more limited territorial jurisdiction based on the presence of an establishment. Courts would carefully circumscribe their jurisdiction where the debtor has only an establishment or assets within their territory or decline jurisdiction altogether in favour of the COMI court. ${ }^{55}$ As practical experience of modified universalism in the real world is spread through instruments such as the Model Law, it is conceivable that countries with a history of long-arm bankruptcy jurisdiction may act increasingly with restraint. ${ }^{56}$

\section{BANKRUPTCY JURISDICTION OVER FOREIGN ENTITIES IN THE US AND THE UK: THE LAW 'ON THE BOOKS'}

This Part compares how bankruptcy jurisdiction over foreign entities is formally configured in the US and UK. The formal account lays the foundation for the switch to functional considerations in Parts IV and V. I use the UK as a comparator partly for pragmatic reasons (it is the system with which I am most familiar), partly because the UK approach has been influential throughout the British common law world, further underscoring the distinctiveness of the US approach. My discussion of UK jurisdiction

\footnotetext{
${ }^{54}$ See, e.g., F Mucciarelli, 'The Unavoidable Persistence of Forum Shopping in European Insolvency Law'<http://papers.ssrn.com/sol3/papers.cfm?abstract id=2375654>. Indeed, without incredibly restrictive rules on COMI shifting, forum shopping would persist even if insolvency law were globally uniform, as shoppers would still shop among different procedural dispensations, different local legal cultures, and/or different interpretations of uniform law. The effect of circuit court splits and local legal culture on the administration of domestic bankruptcy law in the US illustrates the point graphically. ${ }^{55}$ Westbrook (n 43) 786-790.

${ }^{56}$ See further Westbrook (n 43).
} 
focuses on the UK's residual winding-up and restructuring jurisdiction applicable in cases falling outside the scope of the EU Insolvency Regulation. ${ }^{57}$

Both countries formally assert bankruptcy jurisdiction over foreign entities on a more liberal basis than on which they are prepared to recognize other countries' assertions of bankruptcy jurisdiction within their own borders. ${ }^{58}$ And both inevitably use territorial connecting factors as predicates for bankruptcy jurisdiction. However, the formal mix of substantive and procedural rules that facilitate and constrain the exercise of jurisdiction are differently constituted in ways that reflect diversity in the two countries' legal and bankruptcy cultures and approaches to the extraterritorial projection of power.

\section{A. US jurisdiction}

Two claims that critics make about the US's formal rules of bankruptcy jurisdiction cannot be doubted. First, the US does have a low formal barrier of entry to bankruptcy proceedings. Second, the US does make expansive claims about the theoretical reach of its bankruptcy law as regards any corporate debtor, domestic or foreign, that files a US case.

Three provisions of the Bankruptcy Code control entry to the bankruptcy system: sections 109, 301 and 303. These provisions apply to domestic and foreign incorporated entities and to liquidation and reorganization bankruptcies. Simply put, domestic and foreign debtors are treated the same under the Bankruptcy Code. If the requirements are satisfied, a bankruptcy case under chapter 7 or 11 is lawfully commenced.

Section 109 provides that '...only a person that resides or has a domicile, a place of business, or property in the United States...may be a debtor under this title.' The term 'person' is broadly defined to include 'an individual, partnership, and corporation. ${ }^{59}$ The remainder of the statutory language is disjunctive. A person is an eligible debtor if that person can satisfy any one of the eligibility requirements. 'Property' in the US therefore suffices for eligibility. Moreover, courts have settled that the plain meaning of 'property' is any amount of property, how ever small the quantity, and have declined to read into the statute a 'material' or 'minimum' property eligibility threshold. A foreign entity therefore qualifies as a debtor under section 109 if, on the date of the petition, ${ }^{60}$ it has only nominal amounts of US property: cash in a US bank account; ${ }^{61}$ an unearned portion of an attorney's retainer; ${ }^{62}$ shares in a US corporation; ${ }^{63}$ original books and records. ${ }^{64}$ Section

\footnotetext{
${ }^{57}$ Which applies, notwithstanding the UK electorate's vote for 'Brexit' in the referendum on 23 June 2016, until such time as the UK formally withdraws from the EU.

${ }^{58}$ See Rubin v Eurofinance SA [2012] UKSC 46, [2013] 1 AC 236 [46], [126] (Lord Collins) as regards the UK and McCormack (n 11) 839, 841-2 as regards the US.

${ }^{59} 11$ USC $\$ 101(41)$ (2012).

${ }^{60}$ In re Axona International Credit \& Commerce, Ltd 88 BR 597 614-15 (1988).

${ }^{61}$ In re Theresa Mctague (1996) 198 BR 428 (\$194 in bank account); In re Iglesias (1998) 226 BR 721 (\$522 in bank account); In re Globo Comunicacoes E Participacoes SA (Globopar) (2004) 317 BR 235 (\$32,000 in bank account).

${ }^{62}$ In re Global Ocean Carriers Ltd (2000) 251 BR 31 (\$400,000 retainers held in escrow by debtors' US attorney).
} 
301 provides that an eligible debtor can commence a voluntary bankruptcy case under any chapter of the Bankruptcy Code by filing a petition with the bankruptcy court. In prescribed circumstances, creditors may also initiate a chapter 7 or 11 case in respect of an eligible debtor under section $303^{65}$ but US courts routinely dismiss involuntary proceedings commenced by creditors against foreign debtors. ${ }^{66}$ Federal district courts have 'original and exclusive jurisdiction of all cases under title 11. ${ }^{67}$ Bankruptcy courts within each federal district exercise this jurisdiction by referral from the district court. ${ }^{68}$ Thus, if a case is properly commenced by, or in relation to, an eligible debtor under sections 301 or 303 , in accordance with the applicable procedural rules, ${ }^{69}$ federal bankruptcy jurisdiction arises. $^{70}$

By fostering swift and unconstrained access and eschewing barriers to entry that are common in many other countries, such as 'insolvency' eligibility requirements, the US system is highly conducive to bankruptcy forum shopping. The legal framework reflects US bankruptcy culture's deep normative commitment to the idea that debtors

${ }^{63}$ Globopar (n 61) (Brazilian parent holding shares in wholly-owned Delaware subsidiary).

${ }^{64}$ In re Paper I Partners LP (2002) 283 BR 661 (books and records of limited partnerships held by US-based general partner).

${ }^{65}$ Although US law is not nearly as well disposed to hostile creditor-initiated bankruptcies as UK law: see J Kilborn \& A Walters, 'Involuntary Bankruptcy as Debt Collection: Multi-Jurisdictional Lessons in Choosing the Right Tool for the Job' (2013) 87 Am Bankr LJ 123.

${ }^{66}$ In re Board of Directors of Multicanal S.A. (2004) 314 BR 486; In re Compañia de Alimentos Fargo, SA (2007) 376 BR 427; Globopar (n 61) 255-56. In the Suntech case, the hostility of US courts to involuntary filings prompted a settlement between the debtor and holdout bondholders that resulted in a Cayman bankruptcy filing assisted by a US chapter 15 case rather than an involuntary US chapter 11 case: see GW Shuster, Jr \& BW Loveland, "Will Chapter 15 be the "Exclusive Destination" for Foreign Debtors' (2015) 34 Am Bankr Inst J 42-43, 90; A Tang \& C Lam, Wuxi Suntech Power Co., Ltd: The First PRC Reorganisation Involving Shareholders Subject to Foreign Proceedings (INSOL International Case Study No. 7, May 2016).

6728 USC $\$ 1334(\mathrm{a})$.

${ }^{68} 28$ USC \$157(a), (d). Strictly, therefore, bankruptcy courts exercise the jurisdiction of federal district courts. The referral, or 'reference' process, as it is better known, is a mechanism designed to overcome a constitutional separation of powers problem: see Stern v Marshall (2011) 131 S Ct 2594.

${ }^{69}$ Federal Rules of Bankruptcy Procedure rr 1002-1021.

${ }^{70}$ This jurisdiction is both in rem insofar as it relates to the administration of property and in personam insofar as it relates to the debtor and creditors: see Globopar (n 61) 252-54; cf Westbrook (n 43) 783-84. The idea of bankruptcy as a collective, federal in rem proceeding is embedded and goes some way towards explaining why a federal bankruptcy proceeding is predicated on the debtor having property within US territorial jurisdiction. See further R Brubaker, 'One Hundred Years of Federal Bankruptcy Law and Still Clinging to an In Rem Model of Bankruptcy Jurisdiction' (1999) 15 Bankr Dev J 261; Tennesee Student Assistance Corporation v Hood (2004) 541 US 440. 
should presumptively have a fair chance to reorganize without unnecessary, potentially value-destructive, delay. ${ }^{71}$ Early filing is encouraged; litigation over access at the outset of a case is discouraged. ${ }^{72}$ Premature testing of the rationale of the bankruptcy filing or, in a chapter 11 case, of the likelihood of successful reorganization, is discouraged. There is no formal hearing of a voluntary bankruptcy petition. The commencement of a voluntary case in and of itself constitutes the grant of an order for relief. ${ }^{73}$ Thus, issues such as abuse of process or forum non conveniens are not addressed as a matter of course before a case formally commences. The US prefers not to strangle cases at birth. But one consequence of liberal eligibility requirements is that foreign debtors, in theory, can engineer US bankruptcy cases by moving property into the US - for example, depositing dollars in a US bank account - on the eve of a bankruptcy filing.

Commencement of a US case creates a worldwide bankruptcy estate comprised of all legal and equitable interests of the debtor in property 'wherever located' and the debtor can be ordered to turn property over to the estate. ${ }^{74}$ Accordingly, US courts claim extraterritorial jurisdiction over the debtor's worldwide property. ${ }^{75}$ Commencement of a US case also automatically stays individual enforcement action of various kinds against estate property. ${ }^{76}$ As the estate encompasses the debtor's worldwide property, the stay restrains creditors who are subject to US personal jurisdiction from taking enforcement action against the debtor's property anywhere in the world without the permission of the US court ${ }^{77}$ on threat of being held in contempt. ${ }^{78}$ And as US rules of personal jurisdiction based on 'minimum contacts' are liberal, ${ }^{79}$ the scope of the stay is potentially far

\footnotetext{
${ }^{71}$ JL Westbrook et al, A Global View of Business Insolvency Systems (The World Bank 2010) 66.

${ }_{72}^{72}$ Ibid. See further In re SGL Carbon Corporation 200 F 3d 154 ( $3^{\text {rd }}$ Cir 1999).

${ }^{73} 11$ USC $\$ 301(\mathrm{~b})$.

${ }^{74} 11$ USC §541(a)(1); In re Rajapakse (2005) 346 B.R. 346.

${ }^{75} 28$ USC $\S 1334(\mathrm{e})$. The extraterritorial reach of US statutes has been contested in the US in a range of regulatory contexts and, of late, the US Supreme Court has rigorously applied the presumption against extraterritoriality, signalling a willingness to constrain, rather than expand, the exercise of US power: see eg Morrison v National Australia Bank (2010) 561 US 247; Kiobel v Royal Dutch Petroleum Co (2014) 133 S Ct 1659. In the bankruptcy context, there is disagreement concerning the reach of bankruptcy avoiding powers: compare SIPC v Bernard L Madoff Investment Securities (2014) 513 BR 222 and In re Lyondell Chemical Co (2016) 543 BR 417. See further discussion in ER Morrison, 'Extraterritorial Avoidance Actions: Lessons from Madoff' (2014) 9 Brooklyn J Corp Fin \& Com L 268.

${ }^{76} 11$ USC $\$ 362(a)$.

${ }^{77} 11$ USC $\$ 362(\mathrm{~d})$.

${ }^{78} 11$ USC $\$ 362(\mathrm{k})$.

${ }^{79}$ International Shoe $v$ Washington (1945) 326 US 310. As is the case with extraterritoriality (n 75), however, the recent US Supreme Court jurisprudence concerning personal jurisdiction over foreign parties is trending towards restraint: see Goodyear Dunlop Tires Operations, SA v Brown (2011) 564 US 915; J McIntyre Machinery, Ltd v Nicastro (2013) 564 US 873; Daimler AG v Bauman (2014) $134 \mathrm{SCt}$ 746; PJ Borchers, 'The Twilight of the Minimum Contacts Test' (2014) 11 Seton Hall Cir
} 
reaching. Foreign parties who maintain a US presence or who hold US assets that could be targeted for enforcement purposes are wise to be concerned about compliance with the stay. $^{80}$

This legal framework admits of two possible overreaching effects that I characterize as 'asymmetric overreaching'. First, there is the possibility of globally extensive US cases predicated on a thimble full of US property - to mix metaphors, extraterritorial 'mountains' made out of territorial 'molehills'. Second, there is the possibility of asymmetric treatment of creditors within US personal jurisdiction who are bound by the US case and creditors with equivalent claims who are beyond the practical reach of US personal jurisdiction who and can disregard the US case. Yukos ${ }^{81}$ is a case with both features. In Yukos, a Russian oil company acting by its chief financial officer filed a chapter 11 case in Houston, Texas despite having only minimal contacts in the US derived primarily from the deposit of funds in a US bank account shortly before the filing of the petition. As a formal rather than a practical matter the case encompassed Yukos's oil and gas assets all of which were in Russia. But the US stay had a practical, as well as a formal, effect. It prevented foreign banks that conduct business in the US - and that were therefore subject to US general personal jurisdiction - from bidding in an expropriatory tax auction of Yukos's Russian assets organized by the Russian government. ${ }^{82}$

While eligibility and commencement are virtually unrestricted, the Code has three mechanisms that formally check asymmetric overreaching. These are the court's abstention power in section 305, the court's power to dismiss a chapter 11 case for cause in section 1112(b) and the rules that govern coordination of concurrent US and foreign cases in sections 1528-1529. The inquiry under the first two powers is whether or not the case - and the protection and relief that it affords - should be allowed to continue. In other words, these are powers that arise after commencement rather than erecting a screen that must be passed through before commencement. The third mechanism - the coordination rules in sections 1528-1529 - affect both the commencement and scope of a US case.

Under section 305, the court may dismiss or suspend a case at any time if the interests of creditors and the debtor would be better served by dismissal or suspension or, alternatively, if a petition for recognition of a foreign proceeding relating to the same debtor has been granted and the purposes of chapter 15 would be best served by dismissal

Rev 1. For a recent disagreement between the bankruptcy court and the district court in the Southern District of New York as to whether Bahrain-based defendants' use of New York correspondent accounts constituted sufficient minimum contacts for the US courts to assert personal jurisdiction over them in avoidance actions: see Official Committee of

Unsecured Creditors of Arcapita Bank B.S.C.(c) et al v Bahrain Islamic Bank(2015) 529 BR 57 revd (2016) 549 BR 56.

${ }^{80}$ In re Nakash (1996) 190 BR 763; In re Simon 153 F 3d 991 ( $9{ }^{\text {th }}$ Cir 1998); In re Gold \& Honey, Ltd (2013) 410 BR 357.

${ }^{81}$ In re Yukos Oil Co (2005) 321 BR 396.

${ }^{82}$ See MW Winkler, 'Arbitration Without Privity and Russian Oil: The Yukos Case Before the Houston Court' (2006) 27 U Penn J Int'l Ec L 115, 117-118. 
or suspension. Section 305 thus enables the US court to take a step back and defer to foreign proceedings or allow events to unfold elsewhere.

The power to dismiss a chapter 11 case for 'cause' under section 1112(b) is broad and open-ended. The statute enumerates a number of illustrative but non-exhaustive factors upon which the court can act. ${ }^{83}$ It is well settled that chapter 11 cases are susceptible to dismissal for cause if the case is not filed in 'good faith'. This statutory gloss is designed to prevent abuse of the bankruptcy process - in particular, the filing of bankruptcy petitions that lack a valid reorganizational purpose and thus delay creditor enforcement for no good reason. ${ }^{84}$ Both powers have been used to stop forum shopped chapter 11 cases. However, as critics are quick - and correct - to point out, given that there is no initial hearing of the bankruptcy petition, the onus is on parties who object to the US case to file a dismissal motion once the case is up and running. And so, the argument goes, asymmetric cases with skewed global effects based on slim jurisdictional foundations can gather momentum and cause mischief in the meantime. ${ }^{85}$ Moreover, the fact that a debtor manufactured eligibility will not usually provide grounds for dismissal per se. Yukos is again illustrative. The Russian debtor filed its petition in mid-December of 2004. ${ }^{86}$ This prevented Deutsche Bank and other foreign banks from participating in the Russian auction, which took place on 19 December $2004 .{ }^{87}$ Deutsche Bank filed a motion to dismiss the chapter 11 case on 28 December $2004 .^{88}$ The court ultimately dismissed the case, but not for a further two months, and it did so on a 'totality of circumstances' basis. The transfer of funds to a US bank account for the primary purpose of creating US bankruptcy eligibility was a factor in, but not the basis for, the dismissal. ${ }^{89}$

Once a US court has recognized a foreign main proceeding under chapter 15 , section 1528 has two effects. First, a full US bankruptcy case may only be commenced after recognition if the debtor has US assets. Second, the jurisdictional reach of the full US case is reined in. ${ }^{90}$ Things work differently if the full case is filed before the chapter 15 case. In this situation, the full case is in the driver's seat. ${ }^{91}$ But whatever the order of events, the Model Law's imperatives temper the court's jurisdiction in the full case. In particular, section 1529(4) expressly cross references the court's abstention power in section 305 as a source of relief for 'achieving cooperation and coordination' between concurrent proceedings.

${ }^{83} 11$ USC 1112(b)(4). Factors include 'substantial or continuing loss to or diminution of the estate and the absence of a reasonable likelihood of rehabilitation' and specified instances of non-compliance with statutory rules or court orders.

${ }^{84}$ In re SGL Carbon Corporation $200 \mathrm{~F} 3 \mathrm{~d} 154$ ( $3^{\text {rd }}$ Cir 1999); In re Integrated Telecom Express, Inc $384 \mathrm{~F} \mathrm{3d} 108$ ( $3^{\text {rd }}$ Cir 2004).

${ }^{85}$ McCormack (n 11) 838, 840.

${ }^{86}$ In re Yukos Oil Co, Chapter 11 Case No 04-47742-H3-11 (United States Bankruptcy Court, Southern District of Texas), Deutsche Bank AG's Pre-Trial Brief (on file with author).

${ }^{87}$ Ibid 3.

${ }^{88}$ Ibid 4.

${ }^{89}$ In re Yukos Oil Co (2005) 321 BR 396, 410-11.

9011 USC 1528, 1529(2).

${ }^{91} 11$ USC 1529(1). 
Thus, the risk of asymmetric overreaching is limited to cases where no insolvency proceeding is pending or contemplated in the debtor's 'home' jurisdiction, or where an insolvency proceeding is pending in the debtor's home jurisdiction, but the foreign representative has neither sought nor obtained chapter 15 recognition in the US. The cases in this limited batch will often be cases that, at point of filing, Professor Westbrook would characterize as US 'solitary non-main proceedings' - that is proceedings where 'a bankruptcy petition is filed in the United States with respect to a corporate debtor whose center of main interests is in another country, yet bankruptcy has not been filed there. ${ }^{, 92}$

It is cases in this narrow category of solitary non-main proceedings ('SNMPs') that attract the critics' attention. SNMPs have varying profiles. Some SNMPs are US cases filed pre-emptively by forum shoppers to gain an 'first to file' advantage before 'home' proceedings are commenced at the debtor's COMI - cases that are only SNMPs for a while. Yukos is one such case. Another is Cenargo, ${ }^{93}$ in which an English shipping company that carried on business primarily in the UK, Ireland, and elsewhere in Europe, filed a chapter 11 case with the aim, in part, of staying enforcement action by a UK creditor that had security interests in two of the company's vessels. This case produced a stand-off between the US court, which was the first court seised, and the UK court, which later ordered the company into provisional liquidation and administration on the petition of the UK creditor, who was acting in violation of the global US stay.

Other SNMPs are cases where the parties in functional control of the debtor ${ }^{94}$ prefer to conduct a bankruptcy proceeding exclusively in the US and avoid a 'home' filing completely. These tend to be what I call 'legal development' cases - that is, cases where the underdevelopment of restructuring laws and/or the supporting institutional infrastructure in the debtor's home country influences the debtor, often in conjunction with its senior creditors and other stakeholders, to shop for a solution in a mature and relatively more predictable system. In these cases, debtors seek the general advantage of 'better law' as well as more case specific advantages. Avianca and In re Northshore Mainland Services, Inc are cases in point. ${ }^{95}$ The chapter 11 case of Arcapita Bank B.S.C.(c.), a Bahraini investment bank is another example. ${ }^{96}$

The structural problem in SNMP cases is that there is no foreign proceeding to which the US court can defer. ${ }^{97}$ But the concern for critics is that objecting creditors are put to the cost and inconvenience of having to contest US jurisdiction, or institute 'home' proceedings for which US recognition can then be sought, while, in the meantime, the US case is gaining momentum and generating powerful constituencies - such as fee hungry debtor and creditors' committee attorneys - with interests in sustaining it. ${ }^{98}$ Moreover,

\footnotetext{
${ }^{92}$ Westbrook (n 43) 781.

${ }^{93}$ In re Cenargo International Plc (2003) 294 BR 571.

${ }^{94}$ Usually, a powerful constituency of coordinated lenders or bondholders. I discount here the possible impact of distressed debt and claims trading on power dynamics because of space constraints.

${ }^{95}$ See further Part IV below.

${ }^{96}$ See further Part VI below.

${ }^{97}$ In re Globo Comunicacoes E Participacoes SA (Globopar) (2004) 317 BR 235 (fn 13).

${ }^{98}$ McCormack (n 11) 840.
} 
the automatic stay inconveniences creditors who wish to initiate 'home' proceedings but who also have a presence or assets in the US.

\section{B. UK jurisdiction}

UK bankruptcy jurisdiction over foreign entities differs in several respects from the corresponding jurisdiction in the US. First, the UK approach is less unitary. The windingup and schemes of arrangement regimes share nineteenth century origins and a common entry test has evolved governing their foreign application. However, winding-up and schemes differ procedurally and, although schemes are widely used for debt restructuring, they are Companies Act rather than insolvency proceedings. The administration regime is open only to companies formed and registered in the UK, the European Economic Area ${ }^{99}$ and, via a circuitous route, in designated countries whose courts qualify for UK cooperation under section 426 of the Insolvency Act $1986^{100}$ and companies, wherever registered, having their COMIs in an EEA state (with the exception of Denmark). ${ }^{101}$ Jurisdiction as regards company voluntary arrangements is similarly qualified. $^{102}$

Second, commencement of UK insolvency proceedings by, or in relation to, foreign entities often - though not strictly always - requires the court to make an order in the exercise of its discretion. Thus, while the formal procedures vary across the different insolvency regimes, the UK applies a screen at the outset to determine whether cases should be commenced whereas the US allows cases to start and then, if the appropriate motion is filed, determines whether they should continue. This tendency is most pronounced in relation to winding-up and schemes of arrangement, which I will treat as indicative. ${ }^{103}$ It is well established that UK courts can wind up foreign entities as

${ }^{99}$ Insolvency Act 1986 (IA 1986), sch B1, para 111(1A)(a), (b) inserted by the Insolvency Act 1986 (Amendment) Regulations 2005, SI 2005/879. Strictly, the scope of this provision is restricted in the UK to companies registered under the Companies Act 2006 in England and Wales or Scotland. There is separate legislation having the same effect governing companies registered in Northern Ireland.

${ }^{100}$ In re Dallhold Estates (UK) Pty Ltd [1992] BCLC 621 (Ch); In re Tambrook Jersey Ltd [2013] EWCA Civ 576, [2014] Ch 252.

${ }^{101}$ IA 1986, sch B1, para 111(1A)(c), which conforms UK domestic legislation to the EU Insolvency Regulation and reflects the holding in In re BRAC Rent-A-Car International Inc [2003] EWHC $128(\mathrm{Ch})$, [2003] 1 WLR 1421. The exclusion of non-EEA registered entities with non-EEA COMIs is difficult to understand: see McCormack (n 11); G Moss et al, 'A very "consequential" amendment' (2010) 23(4) Insolv Int 57, 58. Confusion over whether a Cayman registered company could be placed in UK administration was one factor influencing the US court's refusal to dismiss a chapter 11 case filed by that entity in In re Monitor Single Lift I, Ltd (2008) 381 BR 455, 468.

${ }^{102}$ IA 1986, s 1(4).

${ }^{103}$ Administrators can be appointed out of court and the company voluntary arrangement procedure is out of court though subject to court challenge. In practice, officeholders prefer the shelter of a court order confirming jurisdiction at the outset to the risk of an ex 
'unregistered companies' under Part V of the Insolvency Act on various grounds, including inability to pay debts. ${ }^{104}$ But invariably the court will make a winding-up order on the petition of a creditor or contributory only after a hearing. Thus, even if the petition is unopposed, the court will inquire into its own jurisdiction before making the order. ${ }^{105}$

Schemes of arrangement involve a two-step court process. The debtor entity first has to apply for a court order convening a scheme approval meeting and, assuming the various classes of creditors or members vote in favour in accordance with the statutory thresholds, the court must then sanction the scheme in order for it to be binding. ${ }^{106}$ While the court does not have to determine jurisdiction at the initial convening hearing - it can and sometimes does defer the question until the sanction hearing ${ }^{107}$ - the debtor and supporting creditors typically require comfort that the whole process will not unravel. Thus, in practice, the jurisdictional question is increasingly aired, albeit without being preclusively resolved, at the initial hearing ${ }^{108}$ and the court holds the debtor and its advisers to a high standard of full and frank disclosure. ${ }^{109}$

Third, the UK does not have formal presumptive eligibility rules of the sort contained in section 109 of the Bankruptcy Code upon which an automatic entitlement to commence bankruptcy proceedings is predicated. Presence of assets within the jurisdiction is neither a necessary nor a sufficient condition for access. The approach is fuzzier and the debtor's eligibility, deriving from jurisdictional contacts, is not decoupled from other considerations concerning the appropriateness of UK jurisdiction, as is the case in the US. The jurisdictional test applied both for the purposes of winding-up and scheme jurisdiction is whether or not the debtor has a 'sufficient connection' with the UK. And given the procedural set up, the court will apply this test as a screen regardless

post challenge by disgruntled stakeholders: see eg S Moore, 'COMI Migration: The Future' (2009) 22(2) Insolv Int 25.

${ }^{104}$ IA 1986, ss 220-229. See generally IF Fletcher, Insolvency in Private International Law $\left(2^{\text {nd }}\right.$ edn, OUP 2005) ch 3.

${ }^{105}$ See, by analogy, In re Rodenstock GmbH [2011] EWHC 1104 (Ch), [2011] Bus LR 1245 [22]-[23].

${ }^{106}$ Companies Act 2006 ss 895-899; Payne (n 41).

${ }^{107}$ See eg In re Rodenstock GmbH [2011] EWHC 1104 (Ch), [2011] Bus LR 1245. The current practice direction, Practice Statement (Companies: Schemes of Arrangement) [2002] 1 WLR 1345, is silent on the point and in need of updating to accommodate the subsequent surge of foreign entity schemes: see D Hamilton, 'A New Direction for Schemes' (2015) 28(8) Insolv Int 126.

${ }^{108}$ See eg Primacom Holding GmbH v Credit Agricole [2011] EWHC 3746 (Ch), [2013] BCC 201; Cortefiel, SA v MEP 11.S.a.r.l. [2012] EWHC 998 (Ch); In re Seat Pagine Gialle SpA [2012] EWHC 3686 (Ch); In re Zlomrex International Finance SA [2013] EWHC 4605 (Ch), [2014] BCC 440; In re Van Gansewinkel Groep BV [2015] EWHC 2151 (Ch), [2016] Bus LR 1046 [55]-[56]; In re Indah Kiat International Finance Co BV [2016] EWHC 246 (Ch), [2016] BCC 418 [85]-[89].

${ }^{109}$ In re Van Gansewinkel Groep BV [2015] EWHC 2151 (Ch), [2016] Bus LR 1046; Nordic Trustee ASA v OGX Petroleo E Gas SA [2016] EWHC 25 (Ch), [2016] Bus LR 121. 
of whether or not a winding-up petition or an application to convene scheme approval meetings is opposed.

According to the oft-cited modern formulation of the 'sufficient connection' test put forward by Knox $\mathrm{J}$ in Re Real Estate Development Co, ${ }^{110}$ there are three 'core requirements':

(1) that there must be a sufficient connection with the UK which may, but does not necessarily have to, consist of assets within the jurisdiction;

(2) that there must be a reasonable possibility if a winding-up order is made, of benefit to those applying for the winding-up order;

(3) one or more persons interested in the distribution of assets of the company must be persons over whom the court can exercise a jurisdiction.

These 'requirements' are not applied mechanically as if they were statutory predicates for the exercise of jurisdiction. ${ }^{11}$ UK courts are generally reluctant to make a winding-up order where the foreign entity has no UK assets or is continuing to trade in its place of incorporation or elsewhere. ${ }^{112}$ However, even in the absence of UK assets, a winding-up order may be made to enable a liquidator to investigate and pursue causes of action under UK law that could produce benefits for creditors. ${ }^{113}$ In exercising their discretion, UK courts invariably consider whether another venue would be more appropriate. ${ }^{114}$ Overall, the analysis of jurisdictional contacts is blended with other factors, including the appropriateness of the UK as a forum and the extent to which a winding-up can feasibly be conducted in the UK for the benefit of parties subject to UK jurisdiction.

The same test is applied, with adjustments, to foreign entity schemes. ${ }^{115}$ As schemes are used to restructure financial obligations rather than collect and distribute assets, 'sufficient connection' is tested by reference to the proposed restructuring objective, not winding-up. ${ }^{116} \mathrm{UK}$ courts focus on the transactional relationships enshrined in the debtor's financing documents and will exercise scheme jurisdiction where creditors' have agreed to their rights being governed expressly by English law, and to

${ }^{110}$ [1991] BCLC 210.

${ }^{111}$ In re Latreefers Inc [2001] BCC 174 (CA) [30] (Morritt LJ). See also Re Rodenstock GmbH [2011] EWHC 1104 (Ch), [2011] Bus LR 1245, [22].

${ }^{112}$ Banco Nacional de Cuba v Cosmos Trading Corp [2000] BCC 910, 915 (CA).

${ }^{113}$ In re a Company (No 00359 of 1987) [1988] Ch 210 (Ch) 210, 221-228; In re Latreefers Inc [2001] BCC 174 (CA).

${ }^{114}$ In re Latreefers Inc [2001] BCC 174, $180(\mathrm{Ch})$; In re Buccament Bay Ltd [2014] EWHC 4776 (Ch), [2015] 1 BCLC 646 [20]; K Dawson, 'The Doctrine of Forum Non Conveniens and the Winding Up of Insolvent Foreign Companies' [2005] JBL 28.

${ }^{115}$ In re Rodenstock GmbH [2011] EWHC 1104 (Ch), [2011] Bus LR 1245 [20]; In re Zlomrex International Finance SA [2013] EWHC 4605 (Ch), [2014] BCC 440 [12]; In re APCOA Parking Holdings GmbH (No 2) [2014] EWCH 3849 (Ch), [2015] Bus LR 374 [208]-[220].

${ }^{116}$ In re Drax Holdings Ltd [2003] EWHC 2743 (Ch); [2004] 1 WLR 1049 [29]-[31]; In re APCOA Parking Holdings GmbH (No 2) [2014] EWCH 3849 (Ch), [2015] Bus LR 374 [215]. 
submit to UK jurisdiction, ${ }^{117}$ even if the debtor's COMI is elsewhere. It is generally assumed that a UK scheme discharging or modifying a foreign entity's English law governed obligations will be recognized in other EU member states under English and EU choice of law principles. ${ }^{118}$ Foreign entities can therefore implement pan-EU schemes without moving their COMIs to the UK. Schemes are also used to modify debt obligations of foreign entities governed by New York law. To create a 'sufficient connection' for UK jurisdiction and export these schemes to the US via chapter 15, foreign entities have used a variety of mechanisms, including COMI migrations, UK establishments and the formation of UK group entities. ${ }^{119}$ Thus, debtors can easily establish UK scheme jurisdiction and the law is highly facilitative of inbound forum shopping. Courts tolerate the manufacturing of jurisdiction through techniques such as COMI migration ${ }^{120}$ or amendment of governing law clauses. ${ }^{121}$ But the court's discretion

${ }^{117}$ In re Rodenstock GmbH [2011] EWHC 1104 (Ch), [2011] Bus LR 1245 [66]-[69]; Primacom Holding GmbH v Credit Agricole [2011] EWHC 3746 (Ch), [2013] BCC 201; Re Vietnam Shipbuilding Industry Group [2013] EWHC 2476 (Ch), [2014] BCC 433; In re APCOA Parking Holdings GmbH (No 2) [2014] EWCH 3849 (Ch), [2015] Bus LR 374 [217]-[218].

${ }^{118}$ In re Drax Holdings Ltd [2003] EWHC 2743 (Ch), [2004] 1 WLR 1049 [30]; In re Rodenstock GmbH [2011] EWHC 1104 (Ch), [2011] Bus LR 1245 [73]-[77]; Magyar Telecom BV [2013] EWHC 3800 (Ch), [2014] BCC 448 [22]-[23]; Regulation (EC) No $593 / 2008$ of the European Parliament and of the Council of 17 June 2008 on the law applicable to contractual obligations (Rome I) [2008] OJ L177/6 art 12(1)(d). Schemes may also qualify for pan-EU recognition under the Recast Brussels Regulation (n 41) though there is some doubt over whether schemes fall within its scope: see eg In re Van Gansewinkel Groep BV [2015] EWHC 2151 (Ch), [2016] Bus LR 1046 and discussion in R Olivares-Caminal et al, Debt Restructuring ( $2^{\text {nd }}$ edn, OUP 2016) $2.127-2.139$.

${ }^{119}$ Text to nn 40-42 and, on what is required for successful COMI migration, see In re Hellas Telecommunications (Luxembourg) II SCA [2010] BCC 295. UK courts cannot open main insolvency proceedings in relation to entities if their COMIs are elsewhere in the EU because of the effect of the EU Insolvency Regulation. According to the Companies Act 2006 s 895(2)(b) a company 'liable to be wound up under the Insolvency Act 1986' may propose a scheme. As schemes are outside the scope of the Regulation, courts have read section 895(2)(b) as referring to their residual winding-up jurisdiction, hence the application of the 'sufficient connection' test: see In re Rodenstock GmbH [2011] EWHC 1104 (Ch), [2011] Bus LR 1245 [17]-[19], [35]-[63]; In re Van Gansewinkel Groep BV [2015] EWHC 2151 (Ch), [2016] Bus LR 1046 [29]-[54]; Payne (n 41). For cases in which schemes were recognized in the US as foreign non-main proceedings based on the presence of an establishment in the foreign jurisdiction see In re Hibu, Inc, Case No 8-14-70323-reg (United States Bankruptcy Court, Eastern District of New York, 27 Feb 2014); In re Winsway Enterprises Holdings Ltd, Case No 16-10833mg (United States Bankruptcy Court, Southern District New York, 16 Jun 2016).

${ }^{120}$ In re Magyar Telecom BV [2013] EWHC 3800 (Ch), [2014] BCC 448; In re Codere Finance (UK) Ltd [2015] EWHC (Ch) 3778 [13]-[19].

${ }^{121}$ In re APCOA Parking Holdings GmbH (No 2) [2014] EWCH 3849 (Ch), [2015] Bus LR 374; In re DTEK Finance BV [2015] EWHC 1164 (Ch). 
is formally bounded by concerns about the enforceability of UK schemes in other jurisdictions. ${ }^{122}$ Courts will not allow cases to proceed that will achieve no practical purpose; expert evidence as to the likelihood of overseas recognition is routinely sought. ${ }^{123}$

The same pragmatism that views jurisdiction as tempered by practicability of enforcement also influences judicial views as to the territorial extent of UK insolvency and restructuring law. A UK winding-up has worldwide effect meaning that it extends to assets wherever situated. ${ }^{124}$ However, courts acknowledge the practical limits of this worldwide claim. ${ }^{125}$ And, in contrast to the US, UK insolvency law has no automatic, worldwide stay. Instead, UK courts use anti-suit injunctions to restrain parties amenable to their personal jurisdiction from grabbing assets overseas in violation of UK rules of distribution and priority. ${ }^{126}$ The powerful preference at common law is for any UK winding-up of a foreign entity to be ancillary to a principal winding up taking place in the entity's place of incorporation. ${ }^{127}$ SNMPs are possible - especially in legal development

${ }^{122}$ In re Rodenstock GmbH [2011] EWHC 1104 (Ch), [2011] Bus LR 1245 [73]-[77]; In re Magyar Telecom BV [2013] EWHC 3800 (Ch), [2014] BCC 448 [21]-[22]; In re DTEK Finance BV [2015] EWHC 1164 (Ch) [19].

${ }^{123}$ In re Rodenstock GmbH [2011] EWHC 1104 (Ch), [2011] Bus LR 1245 [73]-[77]; In re Magyar Telecom BV [2013] EWHC 3800 (Ch), [2014] BCC 448 [19]-[20]; In re APCOA Parking Holdings GmbH (No 2) [2014] EWCH 3849 (Ch) , [2015] Bus LR 374 [246]-[249], [258]-[279] ; In re DTEK Finance BV [2015] EWHC 1164 (Ch) [16].

${ }^{124}$ In re HIH Casualty and General Insurance Ltd [2008] UKHL 21, [2008] 1 WLR 852 [8], [68]-[69]; Singularis Holdings Ltd v PricewaterhouseCoopers [2014] UKPC 36, [2015] AC 1675 [10]; Stichting Shell Pensioenfonds v Krys [2014] UKPC 41, [2015] AC 616 [14]-[15]; Bilta (UK) Ltd v Nazir [2015] UKSC 23, [2016] AC 1 [109]-[110]; Sir Peter Millett, 'Cross-Border Insolvency: The Judicial Approach' (1997) 6 Int Insolv Rev 99 ('The basic rules of UK domestic law are not in doubt: an English winding-up order is deemed to have worldwide effect; and in the winding-up the court applies English law, both procedural and substantive.').

${ }^{125}$ In re International Tin Council [1987] 1 Ch 419 (Ch) 446G-447A; Banco Nacional de Cuba v Cosmos Trading Corp [2000] BCC 910 (CA) 915-916.

${ }^{126}$ Mitchell $v$ Carter [1997] 1 BCLC 673, 687; Stichting Shell Pensioenfonds v Krys [2014] UKPC 41, [2015] AC 616 [14]-[26] (reviewing the authorities). The anti-suit jurisdiction is carefully circumscribed: see Millett (n 124) 106-107. See also Fletcher (n 104) 103-104. The UK's residual approach to personal jurisdiction (ie where EU/EEA law does not apply) is broad but differently configured from the US approach and rests on the amenability of a party to service of process: see CPR Pt 6 . Parties can be served outside the jurisdiction with the permission of the court in certain circumstances: CPR rr 6.30(b); 6.36-6.37; CPR PD 6B para 3.1; Altimo Holdings and Investment Ltd v Kyrgyz Mobil Tel Ltd [2011] UKPC 7; [2012] 1WLR 1804 [71]-[102].

${ }^{127}$ In re Vocalion (Foreign) Limited [1932] 2 Ch 196 (Ch) 206-207; In re Bank of Credit and Commerce International SA (No 10) [1997] Ch 213 (Ch) 238-248; In re HIH Casualty and General Insurance Ltd [2008] UKHL 21, [2008] 1 WLR 852 [8]-[11]; Rubin v Eurofinance SA [2012] UKSC 46, [2013] 1 AC 236 [13], [18]; Singularis Holdings Ltd v PricewaterhouseCoopers [2014] UKPC 36, [2015] AC 1675 [10]; 
cases or cases where there is a technical obstacle to a 'home' proceeding ${ }^{128}$ - but courts prefer to avoid them. Thus, while the worldwide scope of the winding-up jurisdiction as regards assets reflects the UK's imperial past, ${ }^{129}$ the jurisdictional claim is formally more circumspect than its US counterpart. The reach of scheme jurisdiction is similarly bounded by concerns about international recognition and enforcement. Moreover, as a scheme is a Companies Act voting mechanism rather than a formal insolvency proceeding, there is no mandatory stay. UK courts may, though, grant a stay to prevent dissentients from enforcing their claims where a scheme that commands substantial creditor support has been worked out but not yet formally proposed or voted on. ${ }^{130}$ In keeping with the equitable maxim, UK courts prefer not to act in vain.

In sum, then, the UK-US formal comparison supports the critics' position to a considerable extent. Although scheme jurisdiction is conducive to forum shopping through ex ante manipulation of choice of law, UK law and procedure requires the court to inquire into its jurisdiction as a matter of course and practical enforceability concerns temper the extent of the formal jurisdictional claim. Global cases reinforced by global stays do not come about automatically at the flick of a proverbial switch. The formal scope for asymmetric overreach is small. In the US, a domestic bankruptcy case and a foreign entity SNMP case are treated the same statutorily. If the debtor is eligible and files a petition, a globally extensive case, supported by the automatic stay, goes into immediate effect and continues unless the court sua sponte takes up the question of its jurisdiction or until the court is presented with satisfactory grounds to dismiss the case on the motion of an objecting party. The formal scope for asymmetric overreach is considerable especially as international stakeholders amenable to US jurisdiction through connections with financial centres such as New York are automatically in legal jeopardy.

\section{US BANKRUPTCY JURISDICTION OVER FOREIGN ENTITIES IN PRACTICE}

Both the UK and US systems are open for business to bankruptcy forum shoppers and case placers. Both offer 'restructuring friendly' environments in global financial centres. Chapter 11 is seen as being formally more sophisticated than the UK scheme not least because of its rules on class formation, cramdown, debtor-in-possession financing and executory contracts. ${ }^{131}$ But the UK is currently the US's strongest market rival ${ }^{132}$ and the choice between a chapter 11 filing and a UK scheme, especially in the context of

Stichting Shell Pensioenfonds v Krys [2014] UKPC 41, [2015] AC 616 [14]-[15]. For background, see Fletcher (n 104) 211-214.

${ }^{128}$ In re a Company (No 003102 of 1991) ex p Nyckeln Finance Co [1991] BCLC 539 (Ch); In re Buccament Bay Ltd [2014] EWHC 4776 (Ch), [2015] 1 BCLC 646 [21].

${ }^{129}$ L Hoffmann, 'Cross-Border Insolvency: A British Perspective' (1996) 64 Fordham LR 2507.

${ }^{130}$ Bluecrest Mercantile Bv v Vietnam Shipbuilding Industry Group [2013] EWHC 1146 (Comm). Of course, if the scheme is being worked on before the debtor defaults, a stay is unnecessary.

${ }^{131}$ Couwenberg \& Lubben (n 7); McCormack (n 11) 826-828.

${ }^{132}$ Couwenberg \& Lubben (n 7). Whether or not the UK can retain its status as the de facto restructuring capital of Europe post-Brexit remains to be seen. 
financial restructuring, may depend as much on the appetite of key stakeholders for each process as on their perceived formal advantages and disadvantages. We have seen that US bankruptcy jurisdiction is more prone to asymmetric overreach than its UK counterpart. But formal possibilities are one thing, functional realities quite another.

Indeed, it is plausible to suppose that the way that US bankruptcy courts actually exercise jurisdiction in practice in SNMP cases is at least somewhat restrained and jurisdictionally congruent more often than not. Borrowing from Miles Kahler and Kal Raustiala, ${ }^{133}$ by 'jurisdictionally congruent' I mean jurisdiction exercised in a fashion predominantly, if not perfectly, coterminous with the court's own territory that affects parties and assets within the practical limits of the court's enforcement powers. My claim then is that US courts - and case placers - (unsurprisingly) prefer effective power to external projections of ineffective power just as much as their UK counterparts. I develop this point by reference to what I called 'focused restructuring' and the aforementioned legal development cases.

\section{A. Focused restructuring}

For cases to be successful, it makes sense for case placers to structure them in ways that impair the claims of creditors against whom enforcement can realistically be achieved while leaving unimpaired the claims of non-US stakeholders located in jurisdictions which are not guaranteed to provide enforcement assistance to the US court. As Couwenberg and Lubben explain, the flexibility of the creditor classification rules in chapter 11 allows 'the American courts to tailor the chapter 11 procedure to match the scope of the court's power. ${ }^{134}$ Thus, different categories of unsecured creditor can be separately classified and accorded separate treatment - junior bondholders in the financial capital structure can be impaired while trade creditors of the operating business are paid in full. ${ }^{135}$ This means that financial and operational restructuring can be partitioned ex ante through corporate group structures and ex post through bankruptcy law. ${ }^{136}$

Foreign entity bankruptcy cases can therefore take the form of a forensically targeted bond restructuring in the group holding vehicle that 'follows the money' to its source. ${ }^{137}$ If the restructuring deal the non-US debtor needs to do is with the holders of New York law governed high yield bonds who are all amenable to US personal jurisdiction, it makes practical sense to use US chapter 11 to implement that deal regardless of where the debtor's COMI is located. This type of financial restructuring, focused on a specific crisis in the debtor's capital structure, is functionally equivalent to

${ }^{133} \mathrm{~K}$ Raustiala, 'The evolution of territoriality: international relations \& American law' in M Kahler \& BF Walter (eds), Territoriality and Conflict in an Age of Globalization (Cambridge University Press 2006).

${ }^{134}$ Couwenberg \& Lubben (n 7) 741.

${ }^{135}$ Ibid 721.

${ }^{136}$ Professor Rasmussen was alive to this trend a decade ago: see RK Rasmussen, 'Where Are All the Transnational Bankruptcies? The Puzzling Case for Universalism' (2007) 32 Brooklyn J Intl L 983.

${ }^{137}$ See Mayr (n 4), Couwenberg \& Lubben (n 7), Rasmussen (n 136). 
foreign entity schemes of arrangement in the UK. Often, the objective of the case is to impose a largely consensual restructuring, via a prepackaged plan, on a minority of active 'holdout' creditors or a minority of non-opposing creditors who cannot be traced. ${ }^{138}$ The chapter 11 case filed by Chilean bus operator Inversiones Alsacia SA to consummate an exchange offer with its noteholders - mainly US-based asset managers - is a good example. ${ }^{139}$ In this case, the Santiago-based company, which held seven bank accounts in New York, confirmed a prepackaged chapter 11 plan that impaired only senior secured noteholders. Meanwhile, the Chilean trade creditors and employees were paid and the buses continued to run. ${ }^{140}$

With debt overhang remaining a problem for banks in the post-financial crisis world, the shift from bank to high yield debt finance will likely consolidate further and focused restructuring will continue to predominate. As US bankruptcy jurisdiction is exercised congruently in focused restructuring cases, abusive forum shopping, characterized by the filing of asymmetrically skewed cases, is unlikely to be a large problem in practice. Of course, given the scope of the US's formal claims, asymmetric cases can be commenced that constrain creditors amenable to US jurisdiction in relation to non-US assets and contribute to inter-creditor strife. Thus, even though the attempt in Yukos to forestall enforcement of, and subordinate, Russian tax claims was understandable, ${ }^{141}$ criticism of Yukos is justified because a full reorganization of an entity with a Russian COMI binding on assets and claims in Russia was never realistic without the cooperation of the Russian authorities. But Yukos is an outlier. The more asymmetric

${ }^{138}$ Mayr (n 4). Many cases therefore amount to private restructurings that need a formal process for 'belt and braces' purposes. For an account of how modern capital structures are facilitative of private - and therefore focused or concentrated - restructuring see Schwartz (n 38).

${ }^{139}$ SJ Lubben, 'Corporate Bankruptcy Tourists Land in U.S.', New York Times, 31 October 2014.

${ }^{140}$ For an earlier example see In re Global Ocean Carriers Ltd (2000) 251 BR 31. The case is controversial because eligibility was manufactured by the depositing of an attorney's retainer. But the purpose of the filing was to shore up a largely consensual restructuring in which the only impaired creditors were holders of US bond debt. Opinions differ about In re Cenargo International Plc (2003) 294 BR 571, a case in which a UK debtor's pre-emptive US chapter 11 filing led for a while to a stand-off between the US and UK courts. On one view, the debtor's board was using the filing to avoid the management displacement effects of an English insolvency proceeding and impose the US stay on an English secured creditor who had interests in two of Cenargo's vessels. On another view, the US case involved a legitimate attempt at a focused restructuring of US bond debt responding to the most pressing crisis in the capital structure that was designed also to prevent the secured creditor from taking precipitate enforcement action but without impairing its substantive rights: see (2003) 294 BR 571, 577-580, 603 .

${ }^{141}$ Some aspects of the Russian government's tax assessment and enforcement process were subsequently found to have violated article 6 and article 1 of the first protocol of the European Convention on Human Rights: OAO Neftyanaya Kompaniya Yukos v Russia (2012) 54 EHRR 19 (European Court of Human Rights). 
the US case (eg a 'peppercorn' case that purports to affect worldwide assets and claims) and the broader the bankruptcy purpose sought to be achieved, the less likely the case will survive.

\section{B. Legal development cases: Avianca and Northshore Mainland}

Yukos is fair game. The case was eventually flushed but not before the automatic stay had done its work. Criticism of Avianca is harder to understand. To be sure, as the national airline of Colombia, Avianca's COMI and the preponderance of its assets were in Colombia. But this was not a 'peppercorn' case and its US connections were not manufactured. Avianca had planes flying in and out of Miami and New York that were susceptible to creditor seizure in the US. Avianca needed access for liquidity purposes to cash collateral in the form of US credit card receivables held in US accounts. By modern jurisdictional standards, Avianca had a US establishment.

The imperative behind the filing was Avianca's need to renegotiate its aircraft leases, the costs of which were a major drag on its business. The powers of a debtor-inpossession in section 365 of the Bankruptcy Code to assume or reject leases provided Avianca with leverage in this respect. ${ }^{142}$ The chapter 11 case survived a section 305 challenge by a disgruntled creditor and the airline emerged from bankruptcy under new ownership with fresh investment. It operates to this day. Moreover, because Avianca had the economic clout to negotiate a successful out-of-court 'standstill' with its non-US creditors so as to ensure parity of treatment between US creditors and non-US creditors, the bankruptcy court acted in a remarkably restrained and jurisdictionally congruent fashion. If we judge Avianca by reference to the legal and practical context in which it arose, the case epitomizes the 'art of the possible.'

Critics are uneasy about Avianca. Universalists say that the airline should have filed its main proceeding in Colombia. At the time the case commenced (March 2003), Colombia had a four-year-old reorganization law in place, although this did not permit rejection of leases. ${ }^{143}$ Sovereigntists dislike what they see as US encroachment on Colombian sovereignty. But the practical alternatives to an SNMP were for Avianca: (i) to file for reorganization under an untested Colombian law and seek discretionary relief in the US to protect the aircraft and access the cash collateral; $;{ }^{144}$ or (ii) to file concurrent proceedings in Colombia and the US and try to coordinate 'mirror' plans in two jurisdictions with conflicting laws. Given the risks associated with these alternatives, Avianca and its Colombian stakeholders can hardly be faulted for using the US bankruptcy system, well versed as it is in aviation cases, to deal with Avianca's American stakeholders. A reasonable interpretation of Avianca is that the airline, in conjunction with its Colombian stakeholders, chose in real time the option of a plan that would bind its American stakeholders over perceptibly weaker alternatives, involving the pursuit of a

${ }^{142}$ Albeit aircraft lessors have special protections in 11 USC $\S 1110$.

${ }^{143}$ Westbrook (n 43) 787-789.

${ }^{144}$ Under 11 USC $\S 304$, the statutory predecessor of chapter 15 . 
large de facto test case under a relatively new law in a less than robust judicial and institutional environment, ${ }^{145}$ that required active US cooperation to succeed.

Avianca is a 'hard' case that pragmatists and consequentialists find easier to accept than universalists and sovereigntists. With no foreign proceeding to defer to what was the US court supposed to do faced with a foreign debtor that clearly needed relief? Forcibly reallocate the case to Colombia by closing the US case down against the wishes of the debtor and the majority of its US stakeholders and risk damage to the US business in the meantime? The main risk of the creative placement was discrimination against US creditors who were squarely within the US court's enforcement jurisdiction. But the court insisted that US general creditors receive the same treatment as their Colombian counterparts. ${ }^{146} \mathrm{I}$ do not deny that the case leaves difficult choice of law questions unanswered. Universalists favour the application of COMI bankruptcy law and ask why US bankruptcy law should impinge on the aircraft leases. ${ }^{147}$ Perhaps this question could have been addressed in coordinated concurrent proceedings. We will never know. ${ }^{148}$ The purpose of my narrative is to suggest that the exercise of jurisdiction in Avianca was careful not exorbitant. The way the case actually functioned in terms of reach and applicable law can fairly be characterized as equivalent to a territorial insolvency proceeding under the EU Insolvency Regulation. ${ }^{149}$

In re Northshore Mainland Services, Inc ${ }^{150}$ is a legal development case with features that differentiate it from Avianca. Avianca was mostly consensual; the jurisdictional fight in Northshore was merely one battle in a wider inter-stakeholder conflict. Avianca predates US enactment of the Model Law; Northshore arose a decade after the US enacted the Model Law. Finally, and perhaps most significantly, the Northshore case could only ever have succeeded with the active cooperation of the debtor's 'home' court because its objectives were more far reaching.

In Northshore, the Bahamian developer of a huge resort complex called Baha Mar, described in the record as 'one of the most significant single-phase resorts under

${ }^{145}$ The Colombian government only recently agreed a peace deal with the FARC rebels after more than half a century of internal conflict: see 'Colombia nears a peace deal with FARC rebels', New York Times, 23 September 2015; 'Colombia peace deal with FARC is hailed as new model for ending conflicts', The Observer, 26 September 2015; 'FARC peace deal: rebels and Colombian government sign accord to end war', The Guardian, 25 August 2016. The peace deal was narrowly rejected in a referendum: 'Colombia Peace Deal is Defeated, Leaving a Nation in Shock', New York Times, 2 October 2016.

${ }^{146}$ In re Aerovias Nacionales de Colombia S.A. Avianca, Chapter 11 Case Nos. 0311678-ALG, Debtors' Motion and Order for Entry of an Order Authorizing Payment or Honoring of Prepetition Obligations to Certain Creditors Asserting Nominal Claim Amounts Against Debtors' Estates, 4-5 June 2003 (on file with author).

${ }^{147}$ Westbrook (n 43) 788.

${ }^{148}$ More than a decade later, choice of law harmonization in international insolvencies has not progressed far outside the EU and has only recently begun to attract attention at UNCITRAL: see eg Clift (n 27).

${ }^{149}$ EU Insolvency Regulation, recitals (23)-(24), (37)-(38), arts 3(2)-(4), 7, 35.

${ }^{150}$ (2015) 537 BR 192. 
development in the western hemisphere' ${ }^{151}$ ran out of cash before construction could be completed. The project was financed by $\$ 2.45$ billion of inward investment from a Chinese bank. The project got behind schedule with the result that the developer, who had a significant equity stake, could no longer work productively with the main contractor, another Chinese entity. The Bahamian government was stuck between a rock and a hard place. It needed the developer to finish the project for political and economic reasons ${ }^{152}$ while keeping its foreign investors happy.

Several Bahamian registered entities in the developer's group and the group's sole US subsidiary filed chapter 11 cases in the District of Delaware. The US subsidiary had a place of business in Florida and, collectively, the various debtors had approximately $\$ 11.8$ million in US bank accounts. The developer manufactured the eligibility of seven of the Bahamian entities by depositing $\$ 10,000$ per entity in US bank accounts two weeks before the bankruptcy filing. Bankruptcy court approval for a debtor-in-possession facility of $\$ 80$ million to fund payroll and operating expenses was sought and obtained. The developer also sought recognition of the chapter 11 proceedings in the Bahamas.

The Bahamian government responded by petitioning for the winding-up of the Bahamian entities and the appointment of provisional liquidators. The Chinese parties and the government also opposed recognition of the chapter 11 cases, which was duly denied by the Bahamian court. The Chinese parties then asked the Delaware court to dismiss the chapter 11 cases relating to the Bahamian entities on various grounds. The court ruled that the debtors were all clearly eligible to file ${ }^{153}$ and the court refused to dismiss the cases for 'bad faith' filing under section 1112(b). ${ }^{154}$ It accepted (as the developer conceded) that the developer was trying to wrest control of the project away from the Chinese parties. But this did not support a determination that the filing was in 'bad faith'. ${ }^{155}$

Nevertheless, the court dismissed all bar the US subsidiary's case under section 305(a)(1) on the ground that 'the interests of the debtors and creditors would best be served by dismissal'. ${ }^{156}$ In determining whether to dismiss a bankruptcy case under section 305(a)(1) courts weigh and balance several factors. ${ }^{157}$ The court gave some

151 Ibid 196.

${ }^{152}$ According to the record, '[o]nce completed, the Baha Mar Resort will generate nearly 5,000 jobs and is projected to have annual payroll in excess of $\$ 130$ million representing $12 \%$ of the GDP of The Bahamas': ibid. The government is up for reelection in 2017.

${ }^{153}$ Northshore (2015) 537 BR 192, 200-201.

154 Ibid 201-203.

${ }^{155}$ And was prepared to inject new capital: Northshore (2015) 537 BR 192, 197 ('The Developer owns and controls the DIP Lender'). However, the $\$ 80$ million debtor-inpossession facility was conditioned on Bahamian court recognition of the chapter 11 cases.

${ }^{156}$ Ibid 203-208.

157 (1) The economy and efficiency of administration; (2) whether another forum is available to protect the interests of both parties or there is already pending a proceeding in state court; (3) whether federal proceedings are necessary to reach a just and equitable solution; (4) whether there is an alternative means of achieving an equitable distribution of assets; (5) whether the debtor and creditors are able to work out a less expensive out- 
weight to the developer's preference for US reorganization. But the thrust of the dismissal opinion is that this was a massive Bahamian 'single asset real estate' case, which implicated powerful Bahamian national interests, and it was best therefore for the US court to withdraw. In so concluding, the court sidestepped the developer's argument that chapter 11 is superior to the alternatives under Bahamian law although the argument has considerable force. The insolvency system in the Bahamas is based on English law as it stood before the Insolvency Act 1986. The formal alternatives are restricted to liquidation, receivership, and schemes, and the law has not yet caught up even with the late twentieth century trend toward rescue-oriented insolvency law. But even though the court was bullish about the utility of a chapter 11 case 'with all stakeholders participating', it deferred to the home court's view that Bahamian law equipped 'provisional liquidators with limited powers to preserve the Debtors' assets while promoting a scheme/plan of compromise among all stakeholders. ${ }^{, 158}$ The Delaware court recognized the limits of its own jurisdiction and acted accordingly. It allocated governance authority to the home court explicitly out of comity to the Bahamian court and implicitly because a US case was unfeasible. The case illustrates that US courts will defer on something approximating to forum non conveniens grounds where proceedings are initiated in the 'home' jurisdiction.

\section{US REGULATION OF FORUM SHOPPING: TOWARDS FUNCTIONAL CONVERGENCE AND GREATER UNIVERSALISM?}

So far my thesis is that cases like Yukos are probably outliers because, despite the formally more aggressive posture of US bankruptcy law, US courts generally exercise bankruptcy jurisdiction in jurisdictionally congruent ways that reflect feasibility constraints. But what of the objection that the US bankruptcy system's formal configuration still permits the filing of too many needless or abusive cases that would be better screened out of the system on Day One, especially bearing in mind the automatic effects of US filings, combined with the reach of US personal jurisdiction? ${ }^{159}$ Thus, one might argue that the low bar to eligibility in Northshore incentivized the developer to file a needless, asymmetrically skewed chapter 11 case that put other stakeholders in legal

of-court arrangement which better serves all interests in the case; (6) whether a nonfederal insolvency has proceeded so far in those proceedings that it would be costly and time consuming to start afresh with the federal bankruptcy process; and (7) the purpose for which bankruptcy jurisdiction has been sought: Northshore (2015) 537 BR 192, 203204.

${ }^{158}$ Ibid 205-206. At the time of writing, the Baha Mar case was finally approaching resolution. The Chinese bank appointed receivers under its security and the receivers have apparently sold the partially completed resort to an undisclosed buyer: 'Baha Mar to be Sold Twice as Court Process Ends', Tribune 242, 3 October 2016, $<$ http://www.tribune242.com/news/2016/oct/03/baha-mar-be-sold-twice-court-processends/>.

${ }^{159}$ Concerns about the automatic global reach of US law are fueled by divergent international approaches to personal jurisdiction and so must be taken seriously. See $\mathrm{R}$ Michaels, ‘Two Paradigms of Jurisdiction' (2006) 27 Mich J Int'1 L 1003. 
jeopardy and was always destined to be a costly, distracting, and ultimately futile sideshow. Couldn't the US just deter this kind of filing by raising the eligibility threshold for foreign entities and/or insisting that the court apply a forum non conveniens test sua sponte as soon as the case commences?

While the US could consider toughening its eligibility criteria, it is unlikely to go down this path for legal cultural reasons already outlined in Part IIIA. ${ }^{160}$ It will prefer instead to regulate abusive forum shopping through sections 305 and 1112(b) bolstered by considerations of international comity and by procedural mechanisms, including sanctions against abusive filers and their attorneys. There are already moves afoot by the National Bankruptcy Conference, a prestigious group of practitioners, scholars and judges, to persuade Congress to amend section 305 to further limit scope for asymmetrically skewed SNMP cases. ${ }^{161}$ The amendment would give bankruptcy courts power to dismiss or suspend a US bankruptcy case if 'the debtor's center of main interests is not the United States and the court cannot exercise control over either the debtor or the debtor's material assets.' If enacted, the NBC amendment would reinforce chapter 15's inbuilt preference for supplementary jurisdiction and further bias the US system towards jurisdictional congruence. But even without the NBC amendment, which, to my mind, endorses the outcomes in Avianca, Yukos and Northshore, there are reasons to think that the functional gap between US and UK regulation of bankruptcy forum shopping is already narrower than the formal gap.

The first reason rests on an assumption, derived from complexity theory, that legal systems for allocating and coordinating governance authority are complex adaptive systems that evolve. ${ }^{162}$ Yukos and Avianca were decided over ten years ago. At that time, US courts had only recently arrived at the settled view of US law that I described in Part IIIA. ${ }^{163}$ Since then, dynamic interactions between case placers and courts have produced a body of evolving case law on sections 305 and 1112(b) that has likely generated feedback loops that operate recursively to regulate the behaviour of case placers and their forum shopping clientele. ${ }^{164}$ If the odds are that the case will not survive a challenge, it is

${ }^{160}$ On path dependency with particular reference to US exceptionalism in the bankruptcy context see I Ramsay, 'US Exceptionalism, Historical Institutionalism, and the Comparative Study of Consumer Bankruptcy Law' (2015) 87 Temp L Rev 947.

${ }^{161}$ See letter of 27 January 2016 Congress: $<$ http://newnbc.wpengine.com/wpcontent/uploads/2015/07/NBC-Ltr-to-Cong-re-Ch-15-Amendments2.pdf $>$.

${ }^{162}$ See eg J Webb, 'Law, Ethics and Complexity: Complexity Theory \& the Normative Reconstruction of Law' (2005) 52 Clev St L Rev 227.

${ }^{163}$ In re Globo Comunicacoes E Participacoes SA (Globpar) (2004) 317 BR 235 illustrates the point. In Globopar, the bankruptcy court dismissed an involuntary bankruptcy proceeding against a Brazilian entity on grounds of ineligibility and abuse of process. On appeal, the district court reversed for error and remanded the case to the bankruptcy court directing it to consider dismissal under section 305(a)(1).

${ }^{164}$ Webb (n 162) 234 ("Complexity theory...emphasizes the importance of "emergence" - the idea that complexity is a (spontaneous) product of the behavior of the system, in the sense that there is no external telos or design shaping the process, and "feedback" which creates loops in the interaction, so that events, communications, feedback on themselves, sometime instantaneously, sometimes after a number of intervening stages. The critical 
not worth filing unless it would yield a swift, decisive negotiating 'win' between commencement and dismissal. Thus, repeat patterns in governance allocation decisions will have shadow effects that constrain future behaviour. ${ }^{165}$ Any attempt to provide a snapshot of the 'American approach' is inevitably stylized because the decentralized administration of the Bankruptcy Code leaves scope for different local approaches, ${ }^{166}$ which, in turn, influence forum shopping behaviour internally within the US. Thus, in presenting a synthetic view I may have conceded too much ground to the critics. ${ }^{167} \mathrm{Be}$ that as it may, my claim in a nutshell is that the 'American approach' around the turn of the century is not preserved in aspic. Complexity theory suggests that evolving practice under the dismissal standards will inevitably have affected behaviour.

The second reason is that, although there is no formal hearing of a debtor's petition, ${ }^{168}$ US courts do operate various types of process constraint. Procedural sanctions can be applied to attorneys and their clients that will further lengthen the shadow effect of case law applying the dismissal standards. Procedural responses will vary depending on the grounds for dismissal. In the TMT case in which twenty three non-US shipping companies manufactured eligibility in the Southern District of Texas, the bankruptcy court conditioned denial of a motion to dismiss on the debtors furnishing to the estates over $\$ 40$ million of what the court's order described as 'good faith property' stipulated, among other things, to ensure compliance with court orders and provide a fund for payment of any sanctions ordered by the court against one or more of the debtors. ${ }^{169}$ Sanctions against attorneys for bad faith 'peppercorn' filings that serve no meaningful purpose $^{170}$ might well be contemplated on grounds of abuse of process.

But even if the filing is judged to be in good faith, courts can use procedural mechanisms to influence future behaviour. Thus, in Cenargo, the debtor's attorneys were docked $\$ 140,000$ in fees to reflect additional litigation costs attributable to their decision to file only under chapter 11 instead of coordinating concurrent filings in the US and the

point is thus that the system's outputs recursively determine its future inputs.'). On feedback loops in the context of transnational litigation see also PK Bookman, 'Once and Future US Litigation' in PB Stephan (ed), Foreign Court Judgments and the United States Legal System (Brill 2014).

${ }^{165}$ Whytock (n 37) 96-101.

${ }^{166}$ Ramsay (n 160) 953 ('[T]he decentralized implementation of the US Bankruptcy Code allows for experimentation and learning. The persistence of "local legal culture" is one example.'). That said, given filing patterns, it is reasonable to assume that practice in the east coast magnet courts - the Southern District of New York and the District of Delaware - is fairly representative: see $\mathrm{n} 184$ below.

${ }^{167}$ To my knowledge no US Court of Appeals has ever endorsed the theory that a foreign entity's case where eligibility is based on a peppercorn of property has global reach.

${ }^{168}$ The petition is itself an 'order for relief': 11 USC $\$ 301(b)$.

${ }^{169}$ See TMT Procurement Corporation v Vantage Drilling Company 764 F3d $512\left(5^{\text {th }}\right.$ Cir 2014) 516. Another procedural safeguard US courts can deploy where there are concerns about abuse is the appointment of a bankruptcy trustee: see eg In re China Fishery Group Limited (Cayman), Case No 16-11895 (JLG) (United States Bankruptcy Court, Southern District New York, 28 Oct 2016).

${ }^{170}$ Westbrook (n 43) 791. 
UK at the outset. ${ }^{171}$ Clearly courts face challenges in SNMP cases where it is not immediately clear whether the debtor will also file concurrently in its home jurisdiction. But any notion that US courts with long experience in cross-border coordination ${ }^{172}$ will ignore what might be happening elsewhere and move full speed ahead is fanciful. The formal account of US bankruptcy law obscures how judges actually conduct business and assert judicial control. Through managerial styles of judging, ${ }^{173}$ including the use of information gathering devices such as status conferences, judges can and do put the brakes on US cases. A recent case in point is In re Legend International Holdings Inc, in which a chapter 11 case filed by a Delaware entity that had mining interests in Australia was put on hold to await the decision of an Australian court on a conjoined winding-up petition and application for recognition of the chapter $11 .{ }^{174}$

The third reason relates to the universalists' hope, to which I alluded at the end of Part II, that, under conditions of modified universalism, courts will increasingly tend to exercise domestic bankruptcy jurisdiction over foreign entities commensurate with the UNCITRAL Model Law's rules for recognition of foreign main and non-main proceedings. In this respect, Northshore is instructive and provides a synthesis and snapshot of current US thinking. On the one hand, it reflects the US culture of liberal access and bullishness about the utility of chapter 11 - there is no finding that the developer acted in bad faith. On the other hand, it concedes that the case was back to front and allocates governance authority to the Bahamian court in the spirit of universalism. The outcome is significant because it sends the message that chapter 11 cases - even those filed apparently in good faith - will be handled with proper regard for the jurisdiction of the COMI court. ${ }^{175}$ The Legend International Holdings case, referred to in the previous paragraph, is in the same vein. The question, essentially, is one of coordination and US experience with chapter 15 provides a context for courts to await, and synchronize case management with, developments elsewhere. Were Congress to

${ }^{171}$ In re Cenargo International Plc (2003) 294 BR 571.

${ }^{172}$ The Maxwell, Lehman and Nortel cases all involved US courts in extensive crossborder coordination of concurrent proceedings with foreign courts: see eg Peacock (n 22) on coordination in Nortel. On the practice of courts staying proceedings pending determinations in foreign courts as a coordinating device see JL Westbrook, 'International Judicial Negotiation' (2003) 38 Tex Int'l LJ 567.

${ }^{173}$ See, albeit in different contexts, MB Jacoby, 'What Should Judges Do in Chapter 11?' [2015] U Ill LR 571; 'Federalism Form and Function in the Detroit Bankruptcy' (2016) 33 Yale J Reg 55.

${ }^{174}$ [2016] VSC 308 [45]-[48] (Supreme Court of Victoria, Trial Division), affd sub nom Legend Holdings Inc (in liquidation) v Indian Farmers Fertiliser Cooperative Ltd et al [2016] VSCA 151 [33]-[34] (Supreme Court of Victoria, Court of Appeal). The Delaware court later dismissed the chapter 11 case on the motion of the Australian liquidators supported by the US trustee's office. The case exemplifies what Westbrook (n 172) describes as 'international judicial negotiation' because the US case did not move forward independently of the parallel proceeding in the Australian court.

${ }^{175}$ See further Shuster \& Loveland (n 66) citing also to In re Compañia de Alimentos Fargo, SA (2007) 376 BR 427 as evidence of universalist tendencies in the chapter 15 era. 
enact the NBC amendment the trend would accelerate. Federal courts are well versed in doctrines of restraint such as forum non conveniens ${ }^{176}$ and, insofar as the US sticks with the Model Law, these doctrines, applied through the portal of section 305, are likely to lean towards universalism.

For these reasons, we can plausibly conclude that the US approach to regulating bankruptcy forum shopping is approaching functional equivalence with the UK's. Although a jurisdictional test with a forum non conveniens component is not applied on Day One, there are patent and latent mechanisms within the US system that serve similar ends. Although, the US approach to constraining abusive forum shopping is unsurprisingly on a different legal cultural path, rampant forum shopping can be checked despite the low eligibility bar. Furthermore, there are signs that the anti-abuse feedback loop generated by a mixture of constraints (broad standards in sections 305 and 1112(b) allied to procedural mechanisms) is further amplified by the US's generally favourable reception of the UNCITRAL Model Law via chapter 15.

\section{LEGAL DEVELOPMENT \& FORUM SHOPPING}

Universalists have grounds to be optimistic about the trajectory of US law and practice in the last decade. But a fully symmetrical system in which domestic rules of bankruptcy jurisdiction mirror the Model Law's recognition rules will not be inaugurated by modified universalism. Hegemons like the US will prefer to retain flexible access rules so as to preserve their strong position in the market for cases while reserving the capacity to push their regulatory apparatus outwards into transnational regulatory space or to deploy the vehicle of a full plenary bankruptcy as a coordinating mechanism. And while I have made a case for rough functional convergence, part of my argument is that law in action is not static. The US retains the capacity for unilateral assertion of bankruptcy jurisdiction even if, on my account, it currently favours jurisdictional congruence and international coordination. ${ }^{177}$ But even if we assume that modified universalism will persist as a framing principle for transnational insolvency cooperation and that, for the time being, cases like Northshore represent the direction of travel, global power and development imbalances will check the emergence of a symmetrical system.

${ }^{176}$ CA Whytock \& CB Robertson, 'Forum Non Conveniens and the Enforcement of Foreign Judgments' (2011) 111 Colum LR 1444; WS Dodge, 'International Comity in American Law' (2015) 115 Colum LR 1, 15-16, 50-62; PK Bookman, 'Litigation Isolationism' (2015) 67 Stan LR 1081; Westbrook (n 172).

${ }^{177}$ Unilateralism will not be optimal insofar as multilateralism serves US interests: see further Raustiala (n 133). Moreover, the mismatch between rules of personal jurisdiction in the US and Europe, discussed in Michaels (n 159), will tend to reinforce jurisdictional congruence. If overseas courts are resistant to US notions of personal jurisdiction, the reach of the US case will be cabined. The UK Supreme Court's decision in Rubin $v$ Eurofinance $S A$ [2013] 1 AC 236 is an exemplar. Nevertheless, history teaches us that the present, like the past, is contingent. 
Legal development SNMPs, in particular, present universalists and sovereigntists with the problem that not all laws and legal systems are created equally. ${ }^{178}$ Avianca has been criticized as parochial because the subtext is that the US bankruptcy system is superior to the Colombian bankruptcy system. ${ }^{179}$ But Avianca and Northshore suggest that US courts will not lightly succumb to 'better law' arguments. If the US court can act effectively, and with restraint, to facilitate feasible reorganizations, cases may stick. If not, cases are unlikely to stick. Some may worry that vvianca $^{180}$ creates a precedent for hegemons to suck in cases from emerging markets and so stifle the development of local legal systems. And yet, US courts routinely defer to bankruptcy proceedings in emerging countries, not least in South America. ${ }^{181}$ So American 'better law' parochialism is hardly pandemic. Good outcomes in SNMPs that could not be achieved so easily - or at all - in the debtor's home country should not lightly be traded off where the result (for example, the potential collapse of a significant enterprise like Avianca) would harm the local economy. This is a fortiori where good outcomes are achieved in a jurisdictionally congruent manner.

What makes legal development SNMPs tricky is a coordination problem - the lack of any 'home' case to which the SNMP court can defer. Shooing away debtors by applying universalist principle is not attractive to pragmatic courts if the prospects of successful resolution in the home country are uncertain at best, nonexistent at worse. Conversely, legal development SNMPs are precisely the kind of cases that are prone to asymmetric overreaching. The case of Arcapita, a Bahraini investment bank with offices in 'Atlanta, London, Hong Kong and Singapore in addition to its Bahrain headquarters' 182 is illustrative.

${ }^{178}$ The problem afflicts private international law generally: see FK Juenger, 'The Problem with Private International Law' in J Basedow et al (eds), Private International Law in the International Arena (TMC Asser Press 2000).

${ }^{179}$ Westbrook (n 43) 786, 788.

${ }^{180}$ And Arcapita, a paradigmatic legal development case, discussed below.

${ }^{181}$ Shortly after presiding over Avianca, Judge Gropper dismissed a chapter 11 case in deference to an Argentinian proceeding: see In re Board of Directors of Multicanal S.A. (2004) 314 BR 486. In Avianca, he refused to resolve Colombian labour claims, deferring to the Colombian court's adjudication of Colombian law even though the Colombian claimants were keen for him to intervene: In re Aerovias Nacionales de Colombia S.A. Avianca (2006) 345 BR 120. Subsequently, bankruptcy courts have recognized and given effect to Brazilian bankruptcy proceedings in the US on several occasions: In re Rede Energia S.A. (2014) 515 BR 69; In re OAS S.A. (2015) 533 BR 83; In re Petroforte Brasileiro de Petroleo Ltda (2015) 542 BR 899.

${ }^{182}$ In re Arcapita Bank B.S.C.(c) et al., Chapter 11 Case No. 12-11076 (United States Bankruptcy Court, Southern District of New York), Declaration of Henry A Thompson in Support of the Debtors' Chapter 11 Petitions and First Day Motions and in Accordance with Local Rule 1007-2, 19 March 2012, available at $<$ http://cases.gcginc.com/arcapita/pdflib/6 11076.pdf $>$ ('Thompson Declaration'). I gratefully acknowledge the assistance of Tally $\mathrm{M}$ Wiener in setting me straight on the facts of the case and for directing my attention to primary source materials on the Arcapita case docket. 
Arcapita and certain affiliates, including a Cayman subsidiary, filed US chapter 11 cases in New York. The cases were unopposed by the Central Bank of Bahrain and supported by a majority of Arcapita's institutional lenders. Arcapita's stated aim was to restructure a US $\$ 1.1$ billion unsecured murabaha facility guaranteed by the Cayman subsidiary. ${ }^{183}$ Practitioners who worked on the creditor side of the case have suggested that it was placed in the $\mathrm{US}^{184}$ because Bahraini law was not up to the task. ${ }^{185}$ For example, without a worldwide automatic stay, Bahrain law could not stop winding-up proceedings allegedly threatened against an Arcapita subsidiary in the Cayman Islands. ${ }^{186}$ The debtors successfully confirmed a liquidating plan of reorganization. ${ }^{187}$ This success makes the Arcapita bankruptcy a shop window for the US to attract cases from debtors

183 Thompson Declaration (n 182) 6.

${ }^{184}$ Why New York rather than Atlanta, given that Arcapita's principal place of business in the US is in Atlanta is not immediately clear: 28 USC 1410(1). This opens up a nuanced question that space does not permit me to address in detail. The question is how far do venue choice and forum shopping dynamics within the US affect placement of, and practice in, chapter 11 cases filed by foreign entities? There is an extensive literature on internal forum shopping in the domestic US market, a good deal of it responding to Lynn Lopucki's 'race to the bottom' thesis set forth in Courting Failure: How the Competition for Big Cases is Corrupting the Bankruptcy Courts (Michigan University Press 2005). See further MB Jacoby, 'Fast, Cheap, and Creditor-Controlled: Is Corporate Reorganization Failing?' (2006) 54 Buffalo LR 401. Of 316 cases in the Couwenberg \& Lubben (n 7) dataset, 295 were filed in the Southern District of New York or the District of Delaware. As regards foreign entity chapter 11 cases, it is therefore reasonable to treat practice in these east coast magnet courts as a decent proxy for case management in the US bankruptcy system as a whole.

185 JHM Sprayregen et al, 'Arcapita and the Need for Mideast Restructuring Regimes' INSOL World - Fourth Quarter (December 2015) 18.

${ }^{186}$ That subsidiary, Arcapita Investment Holdings Limited (AIHL) became one of the Arcapita Chapter 11 debtors. Subsequent to becoming a Chapter 11 Debtor, AIHL issued a summons seeking ancillary relief from the Grand Court of the Cayman Island.

Thompson Declaration (n 182) 1-2, 9.

${ }^{187}$ In re Arcapita Bank B.S.C.(c) et al., Chapter 11 Case No 12-11076, Findings of Fact, Conclusions of Law, and Order Confirming Second Amended Joint Plan of Reorganization of Arcapita Bank B.S.C.(c) and Related Debtors with Respect to Each Debtor Other than Falcon Gas Storage Company, Inc., Under Chapter 11 of the Bankruptcy Code, 17 June 2013 available at $<$ http://cases.gcginc.com/arcapita/pdflib/1262_11076.pdf $>12$. The plan was a liquidating plan because it contemplated the orderly wind-down of the debtors' investment portfolio on the basis that this would offer the best recovery for creditors. See further In re Arcapita Bank B.S.C.(c) et al., Chapter 11 Case No. 12-11076, Second Amended Disclosure Statement in Support of the Second Amended Joint Plan of Reorganization of Arcapita Bank B.S.C.(c) and Related Debtors Under Chapter 11 of the Bankruptcy Code, 25 April 2013, available at $<$ http://cases.gcginc.com/arcapita/pdflib/1038 11076.pdf $>4$. 
who are financed on the basis of being Shari'ah compliant and who wish to restructure by utilizing pre-bankruptcy Shari'ah structures. ${ }^{188}$

The significant point is that the Arcapita plan impairs some stakeholders and leaves others 'out of the money.' Most stakeholders are in the Middle East outside of US jurisdiction. They may well have received little or nothing in a formal insolvency proceeding regardless of where the case was placed. But this kind of SNMP case demands a high degree of cultural sensitivity having regard to the obvious language and culture gaps. ${ }^{189}$ By English standards, the filing is defensible as a legitimate 'shop' because "what is being attempted is [designed] to achieve a position where resort can be had to the law of a particular jurisdiction, not in order to evade debts but rather with a view to achieving the best outcome for creditors. ${ }^{190}$ It may hasten insolvency law reforms in the Middle East. ${ }^{191}$ What I say here is in no way intended to criticize the bankruptcy court's handling of the Arcapita case. But in this kind of complex, ambitious, transcultural bankruptcy case in which Western restructuring intersects with Islamic finance, the US courts would be wise, for due process and legitimacy reasons, to proceed carefully.

The case involves an extraterritorial assertion of jurisdiction and the imposition of a US discharge on remote claimants. It is not clear how far the Bahrain courts would give effect to that discharge or, to what extent, remote claimants could successfully prosecute their claims against Arcapita's successor entity in Bahrain or elsewhere. ${ }^{192}$ Creditorbacked forum shops like Arcapita raise obvious inter-stakeholder agency problems. Diffuse remote creditors and investors cannot effectively coordinate and so are at the mercy of coordinated senior creditors as regards the governance of the case. Such cases therefore demand robust, transparent procedural protections for junior creditors that courts may find difficult to craft and manage. If we accept at face value the claim that the home country as yet lacks the legal tools and institutional culture to handle a legal development case, the alternative to a 'shopped' chapter 11 is to leave the debtor to flounder. Although a more extreme case than Avianca, Arcapita produces the same conundrum. In a world of power imbalances, should we allow the COMI principle to serve as a vehicle for local reform in emerging countries at the risk of causing economic harm pro tem in individual cases? Or should pragmatism - driven in large part by lenders

${ }^{188}$ As some of the practitioners involved in the case have been quick to advertise: see Sprayregen et al (n 185)

${ }^{189}$ Due to the prevalence of Arab stakeholders, the Notice of Confirmation Order was provided in both English and Arabic.

${ }^{190}$ Re Codere Finance (UK) Ltd [2015] EWHC 3778 (Ch) [18] (Newey J). See also Payne (n 41).

${ }^{191}$ Sprayregen et al (n 185).

192 The Reorganized Debtors in the chapter 11 case are simply 'run off' vehicles. The latest unaudited financial statements for the Cayman parent of the Reorganized Debtor's group indicate that claims have been made against the group in Bahrain although no provision has been made in the accounts: see $<$ http://cases.gcginc.com/arcapita/pdflib/RA\%20Holding\%20FS\%20mar\%202016.pdf $>$. Meanwhile, a 'new' Arcapita, entirely distinct from the Reorganized Debtors has begun trading: < http://www.arcapita.com/>. 
and case placers - prevail? My preference is for the latter but within proper boundaries, controlled by norms, including judicial congruence, feasibility, and due process. Reasonable minds may differ. To work well, my preference demands pro-active, hands on, managerial judging in real time.

\section{CONCLUSION}

No system - certainly not one that wants to attract cases - will be a perfect 'goldilocks' system in which the balance between 'good' and 'bad' forum shopping is 'just right'. Legal frameworks are inevitably subject to under-inclusivity or over-inclusivity problems, although robust and experienced judges armed with broad standards do a good job most of the time. ${ }^{193}$ There will always be troublesome cases, which push the boundaries of jurisdictional congruence into the transnational 'gap' between domestic systems of regulation. Shipping cases, many of which are filed in the US, ${ }^{194}$ are a good example. The assets are mobile, the debtor's COMI often malleable. As that now notorious SNMP case, Cambridge Gas ${ }^{195}$ illustrates, outward projections of power require a favourable reception elsewhere for certain kinds of creative placement to work.

To be sure, the US could take formal steps to differentiate domestic and foreign entity bankruptcies, push the logic of chapter 15 further, and limit the scope of the automatic stay in foreign entity cases to US territory. ${ }^{196}$ But, as I have sought to demonstrate, there are already functional constraints on US bankruptcy jurisdiction. Furthermore, the trend of federal jurisprudence in the wider context of transnational litigation is towards restraint. ${ }^{197}$ Transnational bankruptcy resolution involves real time coordination under conditions of interdependency. Effective jurisdiction is congruent jurisdiction or jurisdiction that will be accepted and enforced by other countries. US

${ }^{193}$ I do not entirely discount the concern that competition for cases among courts could facilitate 'race to the bottom' forum shopping but I am not as pessimistic as some about the capacity of US bankruptcy judges to regulate forum shopping intrusively and with proper regard for the jurisdiction of foreign courts. That said, effective regulation requires judges to switch from the transactional 'hands off' approach often observed in connection with domestic chapter 11 cases to a more managerial style of judging. On 'transactional' versus 'managerial' approaches in the US context, see further Jacoby (n 173) and Jacoby (n 184), 422-433.

${ }^{194}$ Couwenberg \& Lubben (n 7).

${ }^{195}$ Cambridge Gas Transportation Corp v Official Committee of Unsecured Creditors of Navigator Holdings plc [2007] 1 AC 508. On the subsequent negative treatment of Cambridge Gas see Walters (n 1).

${ }^{196}$ Westbrook (n 43) argues for an immediate hearing at which the reach of the automatic stay could be adjusted. There is no doubt - and I have not sought to argue otherwise that the automatic stay can cause much inconvenience where a pre-emptive filing is made in the US. Conversely, a globally effective stay that will be respected is incredibly useful in cases, such as shipping cases, where creditors can target mobile assets anywhere in the world: see E Flaschen et al 'The Realities and Myths of Chapter 11', Lloyd's List, 4 January 2012.

${ }^{197}$ Above nn 75 and 79. 
bankruptcy courts, and their international clientele, it seems, are as well attuned as UK courts to these feasibility considerations. This is not to discount the temptation for a hegemon to overreach. American faith in the global utility of American solutions especially in the legal development context - is undoubtedly strong. Even so, it is important to distinguish the run-of-the-mill cases from the outliers. And, for now, it can be argued that the US's functional bankruptcy jurisdiction in respect of foreign entities is not quite as long-arm as the formal law would suggest.

(C) Adrian Walters 2017

Text 12,212 words 